Some New Evidence on Determinants of Foreign Direct Investment in Developing Countries
An export orientation is the strongest variable explaining why a country attracts foreign direct investment.

Harinder Singh

Kwang W. Jun

The World Bank

International Economics Department International Finance Division

November 1995 
Policy Research Working Paper 1531

\section{Summary findings}

Singh and Jun expand on earlier studies of the determinants of foreign direct investment (FDI) by empirically analyzing various factors - including political risk, business conditions, and macroeconomic variables - that influence direct investment flows to developing countries.

They try to fill a gap in the literature by examining qualitative factors. Using a pooled model of developing countries, they test three groups of hypotheses on what influences direct investment - that political risk matters, that business conditions matter, that macroeconomic variables matter.

Tests of the first hypothesis indicate that a qualitative index of political risk is a significant determinant of FDI flows for countries that have historically attracted high FDI flows. For countries that have not attracted such flows, sociopolitical instability (proxied by work hours lost in industrial disputes) has a negative impact on investment flows.
Tests of the second hypothesis show that a general qualitative index of business operation conditions is an important determinant of FDI in countries that receive high flows. This country group also shows a positive relationship between taxes on international transactions and FDI flows - supporting the "tariff hopping" hypothesis.

Results from tests of the third hypothesis reveal that exports generally, especially manufacturing exports, are a significant determinant of FDI flows for countries in which FDI is high. This hypothesis is supported by standard regression analysis and by Granger causality tests, which indicate that the feedback is predominantly from exports to FDI.

Export orientation is the strongest variable for explaining why a country attracts FDI. This finding is in line with the secular trend toward increasing complementarity between trade and FDI.

This paper - a product of the International Finance Division, International Economics Department - is part of a larger effort in the department to analyze private capital flows and their policy implications for developing countries. Copies of the paper are available free from the World Bank, $1818 \mathrm{H}$ Street NW, Washington, DC 20433. Please contact Sheilah KingWatson, room N3-040, telephone 202-473-1047, fax 202-522-3277, Internet address skingwatson@worldbank.org. November 1995. (41 pages) 


\title{
Some New Evidence on Determinants of Foreign Direct Investment in Developing Countries
}

\author{
Harinder Singh \\ and \\ Kwang W. Jun
}

International Finance Division

International Economics Department

The World Bank

We are grateful to Punam Chuhan, Eduardo Fernandez-Arias, Maxwell Fry, Sudarshan Gooptu, Leonardo Hernandez, Ronald Johannes, Joosung Jun, Nlandu Mamingi, and Persa Economou for useful comments, and Carmini Luther for valuable research assistance. Dr. F.T. Haner, President, Business Environment Risk Intelligence S.A. graciously provided data for the qualitative variables. 



\section{Introduction}

This paper analyses three empirical issues related to the determinants of foreign direct investment (FDI) in developing countries:

- What types of sociopolitical instability are detrimental to FDI flows? Is there a structural difference between countries with high and low FDI flows?

- Does the perception of favorable business operating conditions positively affect FDI flows? Do taxes on international transactions impede FDI?

- What type of exports (primary or manufacturing) are related to FDI? Do export oriented economies attract FDI (exports precede FDI) or do inflows of FDI tend to increase exports (FDI precedes exports)?

An analysis of these questions is particularly relevant because of the renewed interest in FDI as a viable alternative for financing development. The resurgence of interest in FDI is primarily attributable to two sources.

First, as a recent World Bank report points out, the composition of private capital flows in 1990-93 shifted toward non-debt creating flows including FDI and portfolio equity investments ${ }^{1}$. Average annual FDI flows to developing countries between 1987-89 and 1990-93 have more than doubled in nominal value. The increase in FDI flows during the last two years (according to available data) has been quite dramatic: 28 percent between 1991 and 1992, followed by 42 percent increase in 1992-93. Moreover, developing countries at different income levels have harnessed FDI, although middle-income countries have been relatively more successful than lowincome countries in doing so. Sustainability is an issue in portfolio investment, particularly because of its sensitivity to financial market conditions. In contrast, FDI flows driven by structural factors, such as the integration of global production, are expected to be relatively more sustainable. (World Bank 1995).

Second, FDI has some inherent advantages for development: risk sharing, market discipline, export orientation, and the transfer of technology and managerial expertise. Recent trends show that FDI can be an important and stable source of private capital for developing economies, particularly countries that are able to create a hospitable environment for new foreign investments.

\footnotetext{
${ }^{1}$ World Debt Tables 94-95 ( pp: 7-24).
} 
The rest of the paper is organized as follows. Section 2 discusses a theoretical underpinning of direct investment flows, followed by a review of previous empirical studies in Section 3. The next three sections deal with new empirical testing carried out in this paper: discussion of variables (Section 4); description of data (Section 5); and, presentation of empirical results (Section 6). Section 7 provides summary of findings and policy implications.

\section{Theoretical Background}

From a theoretical point of view, three questions dominate the FDI literature: ${ }^{2}$

- Why do national firms evolve into multinational organizations?

- Why do firms locate production in a foreign country rather than licensing or exporting?

- What determines the geographic pattern of FDI flows? that is, on what basis are host countries chosen?

The theoretical foundations addressing the first two questions are well developed. As Letto-Gillies's (1992) comprehensive survey points out, Hymer (1960) was the first to systematically analyze issues relating to the advantages of large multinationals, market imperfections, and control. Vernon (1966) built on the technological advantage theories, analyzing the strategic market implications of the product life cycle. Vernon (1979) reevaluated his own theory by indicating that multinational firms are now more geographically diffused than the product cycle would warrant, and the cycle has shortened considerably.

Caves (1982) developed the rationale for horizontal integration (specialized intangible assets with low marginal costs of expansion) and vertical integration (reduction of uncertainty and building of barriers to entry). Buckley and Casson (1976) extended Coase's (1937) explanation as to why multinationals internalize intermediate markets: internalizing intermediate production processes reduces uncertainty by circumventing market imperfections.

But Dunning $(1973,1981)$ was the first to provide a more comprehensive analysis based on ownership, location, and the advantages of internalization. Dunning's eclectic theory provides some answers about the geographic distribution of FDI by analyzing location factors. His taxonomy of location factors emphasizes possession of raw materials, labor costs, government incentives, and servicing of local markets. Dunning's model has been criticized for being tautological: it provides a taxonomy for a wide variety of variables that may be important. But the taxonomy does not provide theoretical justification of why certain location factors are important.

\footnotetext{
${ }^{2}$ Recent studies -- for example, Fry (1993) -- have also looked into the question of the effects (specifically, spillovers) of FDI.
} 
Lucas (1993) analyzed FDI based on a traditional derived-factor demand of a multipleproduct monopolist. But because his model is based on orthodox neoclassical foundations, potentially important variables other than the cost of capital and labor (such as a proxy for the size of the market) are not included in the analysis.

Casson (1990) has suggested that the theory of FDI is a "logical intersection" of three distinct theories: the theory of international capital markets, which explains the financing and risk-sharing arrangements; the theory of the firm, which describes the location of headquarters, management, and input utilization; and trade theory, which describes location of production and destination of sales. Although each theory provides some insight about the complexity of FDI flows, an integrated theory that combines these elements in an analytically persuasive way has not been developed.

The empirical investigation in this paper focuses on the macroeconomic and sociopolitical determinants that influence the geographic distribution of FDI flows. There are no simple models or strong theoretical foundations to guide an empirical analysis of these issues. However, the results of past studies are employed as an imperfect, but useful guide.

\section{Recent Empirical Studies}

The literature on the determinants of FDI flows based on diverse methodologies is extensive and controversial. Empirical studies that evaluate the determinants of in-bound FDI are generally based on three approaches: micro-oriented econometric study, survey data analysis, and aggregate econometric analysis. A comprehensive survey of the determinants of FDI based on different methodologies is provided in Pearce, Islam, and Sauvant (1992). A brief technical note discusses the pros and cons of each methodology (Appendix II).

Because each approach has its limitations and advantages, methodological pluralism is desirable. One way that we can check the robustness of our results is to run the same issue through different methodological filters. This study approaches the issue at the country level. Consequently, only broad trends about the macroeconomic determinants of gross FDI flows can be discerned. Evaluations of the empirical studies based on the aggregate econometric approach have been made by Agarwal (1980), Schneider and Frey (1985), and Hein (1992).

Although many aggregate econometric studies have been conducted (table 1), a broad consensus on the major determinants of FDI has been elusive. This lack of consensus can be partly attributed to the lack of reliable and accurate data on FDI flows and its potential determinants, particularly at the sectoral level, and the fact that most empirical work has analyzed FDI determinants by pooling a group of countries that may be structurally diverse. In this paper structural differences refer to substantial discrepancies in the basic macroeconomic variables that characterize an economy (see the descriptive data contrasts between low-and high- 
FDI country groups detailed in table 3). This investigation indicates that the empirical results may differ significantly for country groups that are structurally different. ${ }^{3}$

In addition to the traditional economic variables - such as GDP per capita, GDP growth, and wage cost, antecedent factors that may encourage FDI flows include sociopolitical variables.

\subsection{Sociopolitical instability}

Although "political risk" is frequently thought to influence decisions to invest in another country, the empirical results do not always support this hypothesis. Aharoni (1966) revealed that executives rank political instability as the most important variable, apart from market potential. Conversely, Bennett and Green (1972) found that U.S. direct investments are not affected by political instability in the recipient countries. Levis (1979), employing two proxies for political stability obtained mixed results. He found "the absence of aggressive domestic behavior within the political system against groups or officeholders" to be a significant determinant of FDI for the current period, but not for a lagged period. Another variable, the legitimacy of the regime, was found to be significant for a lagged period but not significant for the current period.

Discriminant analysis of fifty eight developing countries by Root and Ahmed (1979) found that "the number of regular (constitutional) changes in government leadership between 1956 and 1967" was significant. However, other political variables, such as the number of internal armed attacks, the degree of nationalism, and colonial affiliation, were not significant.

Schneider and Frey (1985) found a negative relationship between the "number of political strikes and riots in host countries" and "the inflow of foreign direct investment." Nigh (1985) used the COBDAB database, which constructs aggregate measures of intracountry and intercountry conflict and cooperation. He found that for developed countries intercountry political events were more significant determinants of FDI than intracountry events. On the other hand, for developing countries intracountry political events had a more robust relationship with FDI.

More recently, Wheeler and Mody (1992) found a broad principal component measure of administrative efficiency and political risk to be statistically insignificant. Lucas (1993) does not directly incorporate proxies for sociopolitical risk. Rather, he finds episodic dummies for "good events," such as the Asian and Olympic games in Korea, and Aquino's accession in the Philippines, to be positively related to FDI. Conversely, "negative events," such as Sukarno's rule in Indonesia, Park's assassination in Korea, and Marcos' martial law in the Philippines have a negative effect on FDI.

\footnotetext{
${ }^{3}$ In the same vein, Wheeler and Mody (1992) indicates that elasticity estimates differ markedly for countries at different stages of development.
} 
More than ten years ago, Stephen Kobrin (1981) observed:

"The term 'political risk' thus appears constrained from both an analytical and operational viewpoint. What we are, or should be, concerned with is the impact of events which are political in the sense that they arise from power or authority relationships and which affect (or have the potential to affect) the firm's operation. Not the events, qua events, but their potential manifestation as constraints upon foreign investors should be of concern." (p. 71)

The empirical evidence on the impact of political risk is not unequivocal, partly because it is difficult to obtain reliable quantitative estimates of this qualitative phenomenon for an extended period of time, particularly aspects of political risk, which are viewed as a direct constraint by foreign investors. Political instability is a complex phenomenon. Most proxies that are available capture only some aspects of this determinant. Based on this discussion, the following empirical hypothesis is tested:

Hypothesis I: What types of sociopolitical instability negatively affect FDI flows? Is there a structural difference between countries with high or low FDI flows?

\subsection{Business operating conditions}

As Helleiner (1988) points out, investment incentives created by the government, such as tax holidays, appear to play a limited role in intercountry investment decisions. Most of the empirical literature supports the notion that specific incentives do not have a major impact, particularly when these incentives are thought to compensate for other comparative disadvantages. On the other hand, it is generally believed that removing restrictions and providing good business operating conditions will positively affect FDI flows.

Within this context, there is a wide array of government policies that may increase or decrease FDI flows (see the taxonomy provided in Brewer 1993 as an illustration). It is difficult to quantify these policies as a comprehensive explanatory variable. An alternative, which this paper adopts, is to rely on a qualitative index representing the judgments of experts in the field.

One aspect that has received considerable attention is the role of tariff barriers. Test of the hypothesis that protective tariff barriers, by stimulating import-substituting FDI investments, will encourage "tariff hopping" has received mixed results. However, most of the available evidence supports the hypothesis, particularly the analysis of U.S. FDI in the EC. Given these considerations, the empirical hypothesis tested in this paper explores the following questions:

Hypothesis II: Does the overall perception of favorable business operating conditions positively affect FDI flows? Do taxes on international trade result in "tariff hopping"? 
An important controversy about FDI flows concerns the relative success of inward-and outwardoriented determinants. In addition to the size of the domestic market in the host country, open export-oriented economies may be more successful in encouraging FDI flows. Recently, Hein (1992) and Dollar (1992) have found that outward-oriented developing economies (that rely on new export markets) have been relatively successful. Lucas's (1993) investigation of Southeast Asian countries provides some evidence of the relative importance of outward-oriented policies. Specifically, FDI is relatively more elastic with respect to demand for exports than with respect to aggregate domestic demand. If outward-oriented economies are relatively successful in attracting more FDI, the size of the domestic market need not be a handicap. Even small host countries could influence global corporate decisions by encouraging export-oriented policies.

But, the empirical literature does not establish whether FDI flows are attracted by economies that are already export-oriented (exports precede FDI flows) or whether multinational investment causes exports to increase (FDI precedes exports). From a policy point of view, the direction of causality has obvious implications. Based on these considerations, the questions to be explored under this hypothesis are: causality?

Hypothesis 1II: What types of exports are related to FDI flows? What is the direction of

\section{Rationale for Control Variables}

Several variables should be included as controls to test our three sets of hypotheses. They include: market size, wage costs, the exchange rate, home country characteristics, debt equity swaps and private restructuring, export orientation, interregional characteristics, and past FDI.

Market size. The size of the market, typically proxied by the level of GNP, appears to be an important determinant of FDI flows. Bandera and White (1968) found market size to be a significant determinant of U.S. FDI. Schmitz and Bieri (1972) found the one-period-lagged GNP of the EEC to be a significant variable in a FDI demand function. Lunn (1980) also found the one-period-lagged GNP of the EEC to be a significant explanatory variable for U.S. direct investment in Europe. For developing countries, Root and Ahmed (1979), Torrisi (1985), Schneider and Frey (1985), Petrochilas (1989), and Wheeler and Mody (1992) all find market size to be significant.

But, the United Nations Centre on Transnational Corporations (1992) survey cites conflicting evidence for the growth rate of GNP, once market size is included. For example, Lunn (1980) found the growth rate of output to be statistically significant. But although the growth rate lagged in the second period was significant, it had the wrong sign. Because the importance of market size is fairly well established, it is not the focus of this paper. Since our dependent variable is FDI relative to GDP, the relationship with other GDP-related variables on 
the right hand side of the equation may not be unequivocal. We include both per capita GDP (GDPCAP) and the growth rate of GDP (GDP\%) to control for actual and potential market size.

Wage costs. The standard hypothesis holds that lower relative wage costs will encourage "efficiency-seeking" FDI flows. But results do not offer a clear guide. The extensive empirical investigations of the relative wage costs in Canada and the United States indicate that wage differentials are not a significant determinant for industrial countries. Owen (1982), while analyzing the interindustry determinants of foreign direct investment in Canadian manufacturing industries, found labor cost differentials between Canada and the United States to be statistically insignificant. Gupta (1983) found that wages of production workers in Canada (relative to those in the United States) were not a significant determinant in a comprehensive model. This result held for both ordinary least squares (OLS) and two-stage least squares regressions.

However, recent results for developing countries seem to indicate that relative wage costs are a significant determinant of FDI flows. Flamm (1984), Schneider and Frey (1985), Lucas (1993), and Wheeler and Mody (1992) all find a wage cost variable to be significant. We include a real earnings index as a control for real wages (EARN).

Exchange rate. Lucas (1993) contends that the exchange rate may have "a residual role with respect to exchange rate risk, for example, in determining the value of repatriated profits or in threatening restrictions on such remittances" (p. 393). In order to control for this possibility, the real exchange rate is included as a control variable (XRATE).

Home country factors. Culem (1988) analyzed the bilateral flows of direct investment for six industrial countries (Belgium, France, Germany, the Netherlands, the United Kingdom, and the United States,). He found that the home country characteristics of the investing firm (such as growth rates and labor costs) did not improve the performance of the model. Because we are analyzing global FDI flows to developing countries, the opportunity costs of investing abroad for the specific host country are not directly discernible. One would expect a general increase in opportunity costs to influence the size of FDI flows to developing countries, but not the allocation to specific countries. Consequently, in order to control for aggregate supply side effects, we include the average industrial production index of the G-7 countries (computed from the IMF's International Financial Statistics 1993) as a control variable (IPG7).

Debt equity swaps and private restructuring. Since the late 1980 s several developing countries with large debt burdens have implemented debt conversion programs. ${ }^{4}$ Countries with substantial conversion programs include Argentina, Bolivia, Brazil, Chile, Mexico, the Philippines and Venezuela. Components of the debt conversion programs that relate to debt equity swaps and restructuring of institutions are likely to be correlated with FDI flows because these procedures were employed not only to reduce the debt burden but also to encourage foreign investment. The debt equity swaps and private sector restructuring, performed by commercial

\footnotetext{
${ }^{4}$ See Appendix 6 of World Debt Tables 1994-95 for a brief update of debt conversion programs.
} 
banks, relative to the total long-term debt is employed to control for this phenomenon (DSWAP). ${ }^{5}$

Export orientation. There are two reasons for including exports as a control variable. First, there is a widespread perception that "open" economies encourage more confidence and foreign investment. One indicator of openness is the relative size of the export sector. Second, exports should be included as a control variable because of the higher export propensity of foreign firms (Chen, 1994). This issue has generated considerable controversy. For example, Westphal (1979) contended that exports may be correlated with FDI, not because the foreign firms have a greater export orientation but, because they are disproportionately represented in the main export sectors. However, as Chen (1994) correctly points out, this distinction does not negate the overall contribution of foreign firms to the export sector.

Note that if export orientation is a signal and a magnet for attracting foreign firms, exports would Granger cause FDI, whereas if the entry of foreign firms result in greater export orientation, FDI would Granger cause exports. (We explore the direction of causality in Section 6.) Exports relative to GDP are included as a control variable (EXPORTS).

Interregional differences. Because we are using a pooled model, the analysis focuses on attempting to explain variations of FDI flows over time and across countries. The timeseries portion of the data captures intracountry variation. In addition to country-specific economic variables that vary over time, a time dummy is employed to control for other time-related factors.

Intercountry variation presents a methodological dilemma. The interesting cross-country variations (which we are attempting to explain with qualitative variables), generally occur slowly, although the differences may be substantial. Country-specific dummy variables are not included because they will remove this variation, leaving mostly within country variation. But, we need to establish some form of control that will not eliminate most of the interesting intercountry variation. To do this we employ four dummy variables to control for region-specific factors. ${ }^{6}$ Regional differences may exist because FDI flows are known to follow certain discernible characteristics (e.g., "triad pattern"). The regional dummies may also capture some economies of agglomeration.

Lagged dependent variable. FDI flows are likely to require time to adjust to desired levels, depending on the specific constraints faced by a transnational corporation. A simple partial

\footnotetext{
${ }^{5}$ We are grateful to David Hedley of The Institute of International Finance for providing the data on the different components of the debt conversion programs performed by commercial banks.

${ }^{6}$ Wheeler and Mody (1992) have developed a similar rationale for excluding country-specific dummies. Incorporating regional dummies is a traditional procedure for handling this dilemma. For example, Barro (1991) estimates a pooled model with regional dummies to analyze the determinants of economic growth.
} 
adjustment process can incorporate the speed of adjustment (see Pindyck and Rubinfeld 1991: 208-9).

We begin with a simple equation:

$$
\mathrm{FDI}_{\mathrm{t}}^{\mathrm{d}}=B_{\mathrm{o}}+B_{1} P I_{\mathrm{t}}+B_{2} C V_{\mathrm{t}}+E_{\mathrm{t}}
$$

Desired FDI stock at time $t\left(\mathrm{FDI}^{\mathrm{d}}\right)$ is based on political instability $(P I)$ at time $(t)$, a vector of control variables $\left(\mathbf{C V}_{\mathrm{t}}\right)$, and a random error term $E_{\mathrm{t}}$. To see how the speed of adjustment is incorporated in this model, consider the following equation:

$$
\mathrm{FDI}_{\mathrm{t}}-\mathrm{FDI}_{\mathrm{t}-1}=A\left(\mathrm{FDI}_{\mathrm{t}}^{\mathrm{d}}-\mathrm{FDI}_{\mathrm{t}-1}\right)
$$

Equation 2 shows that changes in actual FDI will respond only partially to the difference between desired FDI and past values of FDI. In any given period a desired level of FDI may not be completely realized (as actual FDI in the next period) because of physical and procedural constraints. The parameter $A$ captures the speed of adjustment to a desired FDI level.

When we substitute $\mathrm{FDI}_{\mathrm{t}}^{\mathrm{d}}$ from equation 1 into equation 2 and rearrange, we obtain:

$$
\mathrm{FDI}_{\mathrm{t}}=A B_{\mathrm{o}}+B_{1} A\left(P I_{\mathrm{v}}\right)+B_{2} A(C V)+(1-A) F D I_{\mathrm{t}-1}+A E_{\mathrm{t}}
$$

In addition to the rationale given in a simple stock adjustment model for using the lagged dependent variable as an explanatory variable, two other purposes arise. First, it takes care of any residual autocorrelation that may exist. Second, the lagged dependent variable indirectly incorporates other "omitted" factors that may have negatively influenced FDI in the previous period. Thus the lagged dependent variable is employed as a control variable (RFDI1).

Based on the rationale discussed in this section, the fully specified model (Model 4 in the tables) can be represented as:

$$
\begin{aligned}
& \text { RFDI }=D_{1}(\mathrm{DASIA})+D_{2}(\mathrm{DLA})+\mathrm{D}_{3}(\mathrm{DAFRICA})+D_{4}(\mathrm{DEUROPE}) \\
& +B_{1}(\mathrm{PRI})+B_{2}(\mathrm{IPG} 7)+B_{3}(\mathrm{GDPCAP})+B_{4}(\mathrm{GDPGROW}) \\
& -B_{5}(\mathrm{EARN})+B_{6}(\mathrm{DSWAP})-B_{7}(\mathrm{XRATE})+B_{8}(\mathrm{EXPORTS}) \\
& +B_{9}(\mathrm{RFDI} 1)+E_{\mathrm{v}}
\end{aligned}
$$

DASIA, DLA, DAFRICA and DEUROPE are the intercept dummies for Asia, Latin America, Africa, and Europe respectively. 


\section{Descriptive Data}

The empirical results are based on a pooled model. The analysis covers 1970-93 for thirty one countries. ${ }^{7}$ Countries were chosen based on the availability of consistent data. Note that for each hypothesis, the years and the countries vary depending on the availability of data. ${ }^{8}$

\section{$5.1 \quad$ Dependent variable}

A relative measure of FDI is employed to control for any large country effects. The dependent variable (henceforth referred to as RFDI) is FDI flows in constant dollars relative to real GDP. RFDI is a "net" investment variable in that it excludes repatriated profits. The fact that some developing countries have become exporters of capital may distort the empirical testing. (table 2). Consequently, outward bound FDI is not subtracted out.

\subsection{Rationale for subsample analysis}

One problem with a pooled model is that countries that are structurally different may be forced to exhibit identical coefficients. In this paper we identify countries with low or high-FDI flows over the entire twenty four-year sample period. The rationale for employing the size of FDI flows for subsample analysis is to examine differences between successful countries (those that consistently attract high flows) and unsuccessful countries (those with low average FDI flows). Once the countries are ranked according to average FDI flows, where should the combined sample be split? Brown and others (1975) suggested a Quandt Log-Likelihood Ratio test to objectively determine where the split should be made. ${ }^{9}$ Based on this criterion, a grid-search across the country subsamples was conducted to find an objective point to subdivide the combined sample. For Brazil the grid search indicated that the log ratio reaches a minimum (combined $\log$ ratio of -316.81 ) at an average RFDI value of 94 percent. ${ }^{10}$ The country ranked above Brazil is Colombia, with 1.07 percent. Consequently, countries with an average RFDI of less than 1 percent per year are classified as "low FDI countries": India (.05 percent), Venezuela (.10 percent), Bolivia (.20 percent), Peru (.27 percent), Korea (.32 percent), Madagascar (.33 percent), Pakistan (.34 percent), Turkey (.38 percent), Chile (.50 percent), the Philippines $(.57$ percent), Kenya (.61 percent), Panama (.65 percent), Ghana (.66 percent), Uruguay (.76 percent), Argentina (.77 percent), Indonesia (.87 percent), and Brazil (.94 percent).

\footnotetext{
${ }^{7}$ The empirical test includes two countries -- Singapore and Spain -- that are not presently classified as developing countries. But, they are included because of the long sample period for which (at least in part) they were developing economies and the fact that some previous studies on FDI in developing countries included them.

${ }^{8}$ Details of the countries included for each hypothesis are provided in the notes to the relevant tables.

${ }^{9}$ The maximum change in the structure of the two subsamples occurs at the point where the sum of the log-likelihood ratios of the subsamples reaches a minimum.

${ }^{10}$ The grid search specification employs PRI, RFDI1, TIME, GDPCAP, GDPGROW, and DESWAP as explanatory variables.
} 
Similarly, countries with an average RFDI of more than 1 percent are classified as "highFDI countries": Colombia (1.07 percent), Thailand (1.17 percent), Greece (1.23 percent), Spain (1.25 percent), China (1.29 percent), Mexico (1.49 percent), Portugal (1.50 percent), Egypt (1.76 percent), Ecuador (1.83 percent), Nigeria (2.15 percent), Costa Rica (2.48 percent), Malaysia (4.17 percent), Botswana ( 4.54 percent), and Singapore ( 9.93 percent).

A few countries that are classified as low-FDI countries have attracted high flows in recent years, including Argentina, Chile, and Indonesia (table 2). A country's performance over the entire sample range for the regression analysis is the relevant variable. In general, the countries classified as recipients of high flows have maintained a consistent performance.

\subsection{Descriptive statistics}

Low FDI countries have an average RFDI of .50 percent whereas the high-FDI countries have an average of 2.37 percent (table 3). As expected, countries that received high-FDI flows have per capita income that is almost twice that of low-FDI countries. More revealing is the fact that these high-FDI countries show a stronger correlation between per capita income and RFDI (.45 compared with .05 for low-FDI countries). ${ }^{11}$ The same pattern holds for annual GDP growth rates: high-FDI countries have higher growth rates and these growth rates are more strongly correlated with RFDI (.21 compared with .10). Although the average real earnings index is almost the same for both groups, real earnings have a higher positive correlation in high-FDI countries (.31 compared with .06). Also expected, high-FDI countries have a larger proportion of exports as a share of GDP ( 35.00 percent compared with 20.19 percent). More important for this investigation, the correlation coefficient between exports and RFDI is much higher for highFDI countries (.82) than to for low-FDI countries (.11). In fact, exports are more strongly correlated with RFDI than any other explanatory variable. ${ }^{12}$ This strong relationship dominates the controlled econometric analysis that follows. Table 3 also shows that this important difference between high-and low-FDI countries is driven by manufacturing exports rather than primary product exports. Manufacturing exports have a much higher correlation with FDI flows in high-FDI countries compared with low-FDI countries (.80 compared with .01$)$. For low-FDI countries, primary product exports have a higher share ( 9.26 percent of GDP) than manufacturing exports (4.00 percent of GDP). This implies that a substantial amount of FDI flowing into the low-FDI group may be extractive. ${ }^{13}$

\footnotetext{
${ }^{11}$ Simple correlation coefficients should be viewed with caution and are not a good substitute for controlled analysis. But, they do bring out some salient features of the data set.

${ }^{12}$ This is also evident in the combined sample results presented in the correlation matrix in table 4. For the combined sample, the Pearson correlation for RFDI and EXPORTS is .86. The second highest correlation comes from the political risk variables: for ORI and PRI the corresponding numbers are .60 and .58 , respectively.

${ }^{13}$ Disaggregate studies at the sectoral level must be performed to pin down the precise differences in manufacturing and primary product exports in low-and high-FDI countries.
} 
Not surprisingly, the share of long-term debt that has been converted by debt equity swaps and restructuring (DSWAP) is more positively correlated with FDI flows in low-FDI countries (.18 compared with .01 ). The remaining variables relating to the three hypotheses are discussed in detail in the next section.

\section{Empirical Results}

Based on Leamer's (1985) approach, a range of specifications are estimated to assess the sensitivity of the coefficients of the hypothesized variables. The hypothesis testing can be represented by a simple equation:

$$
R F D I=F(H V, C V)
$$

In addition to specifying the proxy for the hypothesized variable (HV), it is important to specify the vector of control variables (CV) to correctly estimate the equation. We have taken previous empirical work as a guide to the variables that should be included (see section 4). Additional control variables are progressively added to the model to determine how robust the results are to alternative specifications. The inclusion of additional variables can also reveal the extent of multicollinearity in the estimating equation. All models are estimated with ordinary least squares. ${ }^{14}$ Because higher-income countries may attract more absolute flows, all independent variables are represented in real and relative terms (table 4). All estimated results are provided in Appendix I.

\subsection{Sociopolitical instability}

We test the first hypothesis by employing two proxies to capture different aspects of political instability. Specific questions to be examined are: What types of sociopolitical instability negatively affect FDI flows? Is there a structural difference between countries with high or low FDI flows?

Political risk index (PRI). First, we employ a political risk index (PRI) developed by Business Environment Risk Intelligence, S.A. (BERI). About sixty political specialists from around the world evaluate each country with respect to six internal causes of political risk fractionalization of the political spectrum; linguistic, ethnic, and religious fractionalization; and coercive political risk (dependence on and/or importance to a hostile power) - and two symptoms of political risk (societal conflict involving demonstrations and street violence).

\footnotetext{
${ }^{14}$ The economic structure of the sample countries is likely to be dynamic. Given our ignorance about the specification of this structure, a simultaneous equations model (which is more sensitive to specification errors) is considered less desirable. A simultaneous bias test is performed for each hypothesized variable.
} 
The qualitative index generated ranges from 0 (prohibitive risk) to 100 (complete stability). The values determined by the political specialists are averaged for each country annually. The average political risk index for high-FDI countries is 49.12 , compared with 43.54 for low-FDI countries (see table 3). More importantly, the correlation coefficient between PRI and RFDI is more than four times higher in high-FDI countries (.61 compared with .15).

In order to analyze the influence of PRI on FDI flows, a range of specifications are employed to test the robustness of the results. As additional control variables are included, the size of the sample changes based on the availability of data. ${ }^{15}$ The data set suffers from missing observations. As a general rule, if data are not available for a specific variable and time period, the observation is excluded from the regression estimation. ${ }^{16}$ The stability of the coefficient of the hypothesized variable can be assessed as the control variables and the sample size change for different specifications. All results are reported after conducting White's (1980) correction for heteroscedasticity.

Another issue that should be addressed is the problem of autocorrelation. The inclusion of the lagged dependent variable reduces autocorrelation considerably. Because we have a lagged dependent variable on the right hand side, the Durbin-Watson statistic is not strictly applicable, although it does give some indication of the extent of autocorrelation. For each hypothesis, if the alternative Durbin statistic ${ }^{17}$ for Model 3 indicates potential autocorrelation, the results are reported after correction (see the footnotes of the tables for specific details). The results for each specification are discussed below (table 5).

- Model 1: Initially, RFDI is regressed with PRI, GDP\%, GDP per capita, a time dummy (to capture other time-related effects), and lagged FDI (RFDI1). PRI is significant at the 1 percent level (with a t-value of 2.67). The time dummy, GDP per capita, and RFDI1 are also significant. The high t-value of RFDI1 (13.88) and the low value of the adjustment coefficient (A ranging from .11 to .26 in table 5) indicates that the stock adjustment model should be used.

- Model 2: In this specification, real earnings (EARN) and debt equity swaps (DSWAP) are included in as control variables. As expected, the earning coefficient is negative and

\footnotetext{
${ }^{15}$ Another reason for reporting a large number of regressions with different control variables is because of the trade off between the amount of control variables and the availability of data. When less control variables are employed, the available data set is more extensive. As we increase the set of control variables, data availability constraints reduce the number of observations.

${ }^{16}$ As Pindyck and Rubinfeld (1991:. 219-20) point out, if the missing observations dropped are random, the least squares estimator is still unbiased, although there is some loss of efficiency. Because the sample size is fairly large (ranging from ninety seven for the subsample analysis to 443 for some aggregate models), the loss in efficiency is not likely to be an issue.

${ }^{17}$ The Durbin alternative test involves regressing the error term of the primary equation with all the explanatory variables and the lagged error term. A significant t-value for the lagged error term indicates the presence of autocorrelation. This test is reported for Model 3 in the relevant tables. The WDL proxy for the combined model had significant autocorrelation. Consequently, the results in table 7 are reported after correction.
} 
significant. The coefficient for DSWAP is statistically insignificant. PRI is significant at the 1 percent level.

- Model 3: In this specification we include the exchange rate (XRATE), the average industrial production of G-7 countries (IPG7), and the regional dummy variables. IPG7 is generally increasing over time (as manifested by a high correlation of .97 with the time dummy). ${ }^{18}$ Consequently, the significance pattern for IPG7 is similar to that of the time dummy: positive and significant. The exchange rate has the expected negative sign and is significant at the 1 percent level. The regional dummy variables are uniformly negative and significant. PRI continues to be significant at the 1 percent level.

- Model 4: The inclusion of exports relative to GDP in the estimated equation considerably weakens the significance of the PRI coefficient (with a t-value of 1.40). Given that EXPORTS has the strongest correlation with RFDI (see table 4), this result is not surprising. ${ }^{19}$

- Model 5: Pindyck and Rubenfeld (1991, pp. 303-4) have suggested a modified Hausman specification test to assess the simultaneity bias that may be present in the OLS estimates. The two-step procedure involves first estimating an auxiliary equation in which PRI is regressed against exogenous or predetermined variables (in our case lagged PRI and a time trend). In the second step the residuals of this auxiliary equation are included in the original equation as an additional explanatory variable. This test is performed on Model 3. The results indicate that the bias is statistically significant at the 10 percent level (with a $t$-value of 1.78). However, the PRI coefficient continues to be significant at the 1 percent level.

In the next stage of the analysis models are estimated separately for low-and high-FDI countries (table 6). ${ }^{20}$ The model is estimated for the two critical specifications (Models 2 and 3). ${ }^{21}$ In general, the models of the low-FDI countries have a relatively poor fit. The comparative results indicate that PRI is statistically significant for high-FDI countries at the 1 percent level for both models and only at the 10 percent level for the low-FDI group. Moreover, the size of the PRI coefficient is relatively much higher in the high-FDI countries (by approximately a magnitude of four or five). Thus where the stakes are higher (in high-FDI countries), PRI is significantly related to FDI flows.

\footnotetext{
${ }^{18}$ Because of the high correlation, only one of these variables is included in each regression.

${ }^{19}$ There is also a high correlation $(0.72)$ between PRI and EXPORTS, indicating that multicollinearity could be driving down the t-value for PRI.

${ }^{20}$ An F-test score of 4.95 at the 1 percent level indicates that the model should be estimated separately.

${ }^{21}$ We have already established in model 4 that the inclusion of EXPORTS erode the significance of PRI.
} 
Note that the primary focus is on the coefficients of the hypothesized variable, that is to observe whether they are robust as different controls are implemented. The coefficients of the control variables are not subjected to any systematic analysis and thus should be interpreted with caution. Some general comments about the coefficients of the control variables across various specifications should be made. The real earnings variable (EARN) is generally negative, although it is significant in only some specifications of the combined model. The exchange rate variable is generally negative and sometimes significant. Exports and IPG7 are uniformally positive and significant. DSWAP is generally positive and sometimes significant. GDPCAP and GDP\% are generally positive and sometimes significant in the combined sample and the highFDI subsamples. For the low-FDI group, the GDPCAP and GDP\% coefficients have mixed signs and are generally insignificant. ${ }^{22}$

Work days lost (WDL). Kobrin (1981) pointed out that elements of political risk that have a "potential manifestation as constraints upon foreign investors" may be more directly relevant. The annual reports of the International Labor Organization provide aggregate country data about the number of "work days lost" because of industrial or civil strife. This proxy for sociopolitical instability may be more directly relevant for FDI-flows because of the potential costs of disrupted production. Table 2 indicates that low-FDI countries have a relatively higher number of work days lost ( 4.3 percent compared with 2.2 percent).

In order to evaluate the effect of this variable on FDI, the same specifications employed for PRI are repeated for work days lost (WDL). ${ }^{23}$ A number of patterns emerge from this analysis (table 7). WDL is significant at the 10 percent level for Model 3 and Model 5. But when exports are included as an explanatory variable in Model 4, WDL becomes statistically insignificant (multicollinearity may be one reason; the correlation between WDL and exports is .31). The Hausman test for simultaneous equation bias (Model 5) indicates that the relationship between RFDI and WDL is strengthened marginally once the test is implemented (using predetermined $\mathrm{WDL}_{\mathrm{t}-1}$ and a time trend as explanatory variables in the auxiliary equation).

In contrast to PRI, the overall qualitative measure of political risk in which the regressions are estimated separately for high-and low-FDI countries, the relationship between WDL and RFDI is more significant in the low-FDI countries (table 8). For low-FDI countries WDL is significant at the 1 percent level in Model 2 and the 10 percent level in Model 3. Although PRI, indirectly incorporates WDL, if both variables are included in Model 3, a tstatistic of 2.32 is obtained for PRI and -.56 for WDL. ${ }^{24}$ The two coefficients jointly have an Fvalue of 5.27, which rejects the null hypothesis of zero coefficients for both variables at the 1 percent level.

\footnotetext{
22 This uneven and contrary result for the low-FDI countries is not surprising, given the low correlation between RFDI and GDPCAP (0.05) and RFDI and GDPGROW (0.10).

${ }^{23}$ For the WDL proxy, the Durbin alternative test indicates the presence of first order autocorrelation at the 5 percent level. Consequently, all results in table 3 are reported after correcting for the first-order serial correlation.

${ }^{24}$ The Pearson correlation between PRI and WDL is -.24 .
} 
Two caveats about WDL must be mentioned. Almost every country has some missing observations, which reduces the sample size (see ILO annual reports for details). The data may have a self-selection bias in that some countries may not report data when there are major interruptions in the production process. But this bias, if it exists, will make it more difficult to reject the null hypothesis (no relationship). The results should be interpreted with caution, particularly in view of the missing observations.

Another variable analyzed as a proxy for sociopolitical instability (a political rights index) gave uneven results, possibly because of the narrow range of the index. ${ }^{25}$ The relationship was initially positive, but as additional control variables were included it became negative. The significance pattern was not robust in the subsamples of high-and low-FDI countries.

\subsection{Business Operating Conditions}

Although, as Helleiner (1988) indicates, specific investment incentives established by the government appear to play a limited role in intercountry investment decisions, there is a general belief that conducive business operating conditions are necessary for attracting FDI. In order to evaluate this contention (Hypothesis II), we analyze two proxies for a hospitable business environment.

Operation risk index (ORI). An interesting index developed by BERI is the operation risk index (ORI) which assesses the general business climate. A panel of 105 experts from around the world evaluate each country on the basis of two criteria: the extent to which nationals are given preferential treatment and the general quality of the business climate. A wide range of factors are evaluated, including political continuity, attitude toward foreign investors, balance of payments performance, economic growth, enforceability of contracts, currency convertibility, and infrastructure and local management. This qualitative index ranges from 0 (unacceptable business conditions) to 100 (superior operating conditions).

Table 3 indicates that, as expected, ORI is relatively higher in the high-FDI countries (50.5 compared with 43.6). What is remarkable is the low correlation between RFDI and ORI in low-FDI countries (.05) and the high, positive correlation in the high-FDI countries (.67).

The empirical analysis of ORI indicates that it is statistically significant in all the specifications in the combined model (table 9). Note that GDP\% is not employed as a control variable because it is part of the index evaluation criteria. The subgroup analysis shows that the relationship between RFDI and ORI is less robust for low-FDI countries than for high-FDI countries (table 10). The size of the coefficients of ORI for the high-FDI group are

\footnotetext{
${ }^{25}$ The political rights index, originally developed by Gastil and published by Freedom House (various issues of "Freedom in the World"), ranges from 7 (not free) to 1 (completely free).
} 
approximately twice that of the corresponding coefficients of the low-FDI group, implying that business operating conditions are more important for attracting FDI flows in the high-FDI group.

Taxes on international trade and transactions (ITAX). Government Finance Statistics (GFS), published annually by the IMF, reports the amount of revenues accruing to governments as taxes on international trade and transactions (table A, item 6). These tax revenues, obtained primarily from import and customs duties, are normalized by the total tax revenue to obtain the relative tax burden borne by the international sector (ITAX).

From Table 3 we can see that the relative tax revenues from the trade sector are only marginally lower in the high-FDI countries (16.5 percent compared with 17.1 percent). In both high-and low-FDI countries the simple correlation between RFDI and ITAX is small and negative. Thus, it is not surprising that when ITAX is regressed against RFDI without any controls, the relationship is negative and insignificant (table 11).

But, in Model 2, once controls are introduced for market size (GDPCAP and GDP\%), the relationship between ITAX and RFDI becomes positive and significant. Because higher tax revenues from the trade sector may simply reflect higher turnover, exports relative to GDP is employed as a control variable in all specifications (EXPORTS). ITAX continues to be significant in alternative specifications of Model 3 and Model 4. The simultaneous bias test erodes the significance of the relationship to the 10 percent level (ITAX has a $t$ - value of 1.81 in Model 5). This result indicates "tariff hopping" behavior in FDI flows to avoid trade-related taxes and take advantage of the host market.

The separate regressions run for low-and high-FDI groups indicate that the positive relationship between ITAX and RFDI in the combined sample is driven by the high-FDI group (table 12). For the low-FDI countries, the relationship between ITAX and RFDI is negative and insignificant. In contrast, for high-FDI countries the relationship is positive and significant for both Model 3 and Model 4, indicating that "tariff hopping" is prevalent in this group. ${ }^{26}$

One caveat about the ITAX proxy should be made: government finance statistics are only as good as the quality of the data provided by the respective agencies. As a result, there may be considerable variation in the accuracy of the revenue estimates across countries.

\subsection{Export Orientation and FDI}

When exports are employed as a control variable in the combined regressions (Model 4), it is consistently a significant determinant of RFDI (see tables 5,7, and 9). In fact, one statistical regularity that is robust in all the models (discussed above) is that export orientation is the single

\footnotetext{
${ }^{26}$ The per capita GDP of the high-FDI group is almost twice that of the low-FDI group (see table 3). In fact, if our entire sample is sorted by per capita GDP (high-and low-income groups) rather than by average FDI flows (high-and low-FDI groups), the results for the two groups correspond closely.
} 
most important determinant of FDI flows. In this section we analyze this crucial linkage, determining the type of exports that are related to FDI flows, and the direction of causality (Hypothesis III).

FDI and sectoral exports. The first two regressions indicate that exports in the high-FDI countries are a significant determinant of FDI, whereas in low-FDI countries exports do not play a significant role (table 13). When the model is estimated for manufacturing exports (MFEXP), the results are similar.

In the high-FDI group the coefficient on MFEXP is almost twice that of EXPORTS, indicating that in the high-FDI group the manufacturing component of exports is a driving force compared with overall exports. This notion is corroborated by the results for the primary product exports. In the primary export sector the relationship between PPEXP and RFDI is statistically insignificant in both the high-and low-FDI countries. Exports in general, and manufacturing exports in particular, are a significant determinant in high-FDI countries.

Exports and FDI: causality results. The previous analysis indicates that exports (particularly manufacturing exports) are a significant determinant of FDI flows in high-FDI countries. But the question remains as to whether export-oriented economies attracted FDI (exports preceded FDI) or foreign investment encouraged higher exports (FDI preceded exports). To answer this question, we perform Granger causality tests for each country in the high-FDI group. As Leamer (1985) points out, Granger causality does not imply "causality" as defined in a layman's terms, but rather "precedence" in a lead-lag relationship.

"Augmented" Granger causality tests were conducted - in addition to past values of the dependent variable, past values of GDP per capita, GDP growth, and IPG7 were included before the additional explanatory power of the hypothesized variable was tested. The results should be interpreted with caution because the estimates are likely to suffer from a small-sample bias (annual observations for each country range from twenty to twenty three years). For the countryspecific tests, three annual lags are employed in order to conserve degrees of freedom, the purpose here is to observe the general direction of the results rather than rely on any single result.

The results indicate that for some countries (Thailand: 1 percent significance; Ecuador and Portugal 5 percent significance; and Greece and Singapore, 10 percent significance) exports Granger cause FDI (table 14). The only country in which FDI Granger causes exports is Singapore ( 10 percent significance level), suggesting a b-directional causality. For other countries the results are insignificant. ${ }^{27} \mathrm{~A}$ combined test for the five countries that showed significant feedback from exports to FDI indicates relatively stronger feedback from exports to FDI.

\footnotetext{
${ }^{27}$ Singapore receives the most FDI, relatively for any country in our sample. Consequently, it is conceivable that the feedback from FDI to exports is not statistically significant for other countries because FDI is not large enough to influence overall exports. Results for specific sectoral exports may be different.
} 
The five countries that had significant feedback from exports to FDI also show significant feedback from manufacturing exports to FDI. Again for Singapore, there is feedback from FDI to manufacturing exports. Although the dynamic relationship between FDI and EXPORTS is likely to be simultaneous, the results support the general notion that exports induce FDI.

\section{Conclusions and Policy Implications}

Without placing too much weight on a single regression, the following patterns emerge from our analysis:

- Because sociopolitical instability is a complex phenomenon, regression results differ substantially when different proxies are employed to capture the relationship. The significance of a broad-based qualitative political risk index is greater for the high-FDI group.

- Work days lost in production, a variable that is more directly and immediately relevant for production efficiency, is more significant for low-FDI countries.

- Once the relative size of exports is introduced as a control variable, the influence of these proxies of political instability on FDI flows erode substantially. This change may not be surprising, given that EXPORTS has the strongest correlation with FDI flows, particularly in high-FDI countries. On balance, the export orientation of the country seems to matter most.

- A qualitative index for general business conditions is a significant factor for FDI flows particularly in the high-FDI group.

- Among the high-FDI countries, there is evidence of "tariff hopping," as tax revenues from international trade and transactions are positively related to FDI flows once market size and other economic variables are taken into consideration.

- Exports, particularly manufacturing exports, are a significant determinant of FDI flows for high-FDI countries, but not for low-FDI countries.

- Causality tests indicate that although the dynamic relationship between exports and FDI is likely to be simultaneous to some extent, there is stronger feedback from exports to FDI.

The results provide insight on another important issue: countries that have historically high-or low-FDI flows are structurally different (in terms of the characteristics discussed in table 3 ), and the tested hypotheses differ when the two groups are analyzed separately. This finding may partly explain why tests on the determinants of FDI have been mixed and inconclusive in past aggregate studies. Since the results may be sensitive to the way the different structural 
groups are defined and the thresholds set for demarcating groups, more intensive research on the differences in the structure of country groups relative to the testing of macroeconomic hypotheses would be warranted.

Fry (1993), while analyzing the impact of FDI flows, found a structural difference between country groups. For a control group of eleven developing countries, FDI is associated with reduced domestic investment. But, in six Pacific Basin market economies, FDI raises domestic investment by the full extent of the flow. Viewed in this context, it should be understandable that the determinants of FDI flows are different for high-and low-FDI countries.

Several policy implications flow from these results. First, for countries with relatively low-FDI flows, sociopolitical instability manifested in work hours lost is a significant deterrent to FDI flows. Given that FDI operations in the low-FDI group are likely to be labor intensive, a higher premium appears to be placed on labor relations. ${ }^{28}$ A priority for these countries should be to stabilize labor relations and the working environment to attract FDI inflows. For countries that receive relatively high-FDI flows, perceptions of overall political stability have a significant influence on FDI flows. In the high-FDI group direct investment is likely to be capital intensive, requiring a relatively more substantive and long-term commitment. ${ }^{29}$ Consequently, overall perceptions of political stability play a significant role in sustaining high level of FDI flows.

Second, a similar rationale can be applied for favorable business operating conditions. Operation risk index seems to be a more significant determinant in the high-FDI group. This finding is consistent with the general notion that some developing countries are not seriously considered by transnational firms until they have achieved a reasonable level of corporate hospitality. A higher relative burden of revenues raised from international trade does not appear to be detrimental to FDI flows for the high-FDI countries. But this does not mean that taxing international trade is an advisable policy option, as other costs, such as efficiency distortions and the opportunity costs of higher foregone trade, are likely to arise.

Third, the results support the notion that export orientation is a significant determinant of FDI flows for high-FDI countries. In fact, the relative size of the export sector is the strongest explanatory variable for FDI flows. In particular, manufacturing exports play a critical role. This inference is strengthened by causality tests, which indicate that exports precede FDI flows. The sample data do not indicate a relatively high feedback from FDI to exports. On balance, because exports are the strongest explanatory variable for FDI flows and there is little evidence on feedback from FDI to exports, even fairly-well established developing countries should seek alternative ways to develop a vibrant export sector under a liberalized trade regime as a pragmatic way to encourage consistent FDI flows.

\footnotetext{
${ }^{28}$ This issue must be investigated more extensively by analyzing FDI flows of specific industries having different capital-labor intensities, with labor relations variables.

${ }^{29}$ Again, only sectoral FDI data analysis can pin down the relationship between capital intensive FDI and perceptions of overall political stability.
} 


\section{Appendix I}

Table 1: Summary of Five Aggregate Studies

\begin{tabular}{|c|c|c|c|}
\hline $\begin{array}{l}\text { Authorlyear; } \\
\text { dependent } \\
\text { variable }\end{array}$ & $\begin{array}{l}\text { Sample years; } \\
\text { number of } \\
\text { countries }\end{array}$ & $\begin{array}{l}\text { Significant } \\
\text { variables }\end{array}$ & $\begin{array}{l}\text { General } \\
\text { comments }\end{array}$ \\
\hline $\begin{array}{l}\text { Root and Ahmed } \\
(1977) ; \\
\text { Average per capita FDI }\end{array}$ & $\begin{array}{l}58 \text { developing } \\
\text { countries; } \\
1966-70\end{array}$ & $\begin{array}{l}\text { Per capita GDP, GDP growth rate, } \\
\text { economic integration, urbanization. }\end{array}$ & Employed discriminant analysis \\
\hline $\begin{array}{l}\text { Nigh (1984); } \\
\text { U.S. manufacturing } \\
\text { investment }\end{array}$ & $\begin{array}{l}24 \text { countries; } \\
1954-1975\end{array}$ & $\begin{array}{l}\text { Indicators of international conflict } \\
\text { and cooperation, internal conflict, } \\
\text { GDP change }\end{array}$ & $\begin{array}{l}\text { Did not control for other } \\
\text { economic factors; political data } \\
\text { detailed and comprehensive }\end{array}$ \\
\hline $\begin{array}{l}\text { Schneider and Frey } \\
(1985) ; \\
\text { Net per capita FDI }\end{array}$ & $\begin{array}{l}54 \text { developing } \\
\text { countries; } \\
1976,1979 \\
1980\end{array}$ & $\begin{array}{l}\text { Real per capita GNP, inflation, } \\
\text { Balance of Payment deficit, wage } \\
\text { cost, credit rating, political } \\
\text { instability. }\end{array}$ & $\begin{array}{l}\text { Incorporated both economic } \\
\text { and political variables }\end{array}$ \\
\hline $\begin{array}{l}\text { Wheeler and Mody } \\
\text { (1992); } \\
\text { Capital exports. } \\
\text { of U.S. companies }\end{array}$ & $\begin{array}{l}42 \text { countries; } \\
1982-88\end{array}$ & $\begin{array}{l}\text { Labor cost, market size, level of } \\
\text { FDI, infrastructure }\end{array}$ & $\begin{array}{l}\text { Employed qualitative data; } \\
\text { tested for stability of results }\end{array}$ \\
\hline $\begin{array}{l}\text { Lucas (1993); Real net } \\
\text { FDI }\end{array}$ & $\begin{array}{l}7 \text { Southeast } \\
\text { Asian } \\
\text { countries; } \\
1961-87\end{array}$ & Real wages, industrial disputes & $\begin{array}{l}\text { Model based on production } \\
\text { function with few controls. }\end{array}$ \\
\hline
\end{tabular}


Table 2: Sample Countries and Real Net FDI Flows (RFDI) - Percentage of GDP

\begin{tabular}{|c|c|c|c|c|}
\hline Country & 1990 & 1991 & 1992 & 1993 \\
\hline Argentina & 1.61 & 1.97 & 3.06 & 5.25 \\
\hline Bolivia & .51 & .93 & 1.57 & 2.89 \\
\hline Botswana & 1.57 & 1.70 & 2.13 & 2.30 \\
\hline Brazil & .27 & .29 & .44 & .28 \\
\hline Chile & .87 & 1.85 & 2.17 & 2.76 \\
\hline China & .84 & .98 & 2.19 & 6.23 \\
\hline Costa Rica & 2.79 & 2.99 & 3.39 & 4.88 \\
\hline Colombia & 1.08 & .97 & 1.59 & 1.95 \\
\hline Ecuador & .60 & .59 & .56 & .89 \\
\hline Egypt & 1.65 & .56 & .99 & 1.28 \\
\hline Ghana & .22 & .29 & .31 & .39 \\
\hline Greece & 1.79 & 1.98 & 1.97 & 1.98 \\
\hline India & .045 & .038 & .039 & .083 \\
\hline Indonesia & 1.04 & 1.32 & 1.47 & 1.87 \\
\hline Kenya & .54 & .18 & .05 & .02 \\
\hline Korea, Rep. of & .37 & .53 & .25 & .25 \\
\hline Madagascar & .69 & .45 & .68 & 1.13 \\
\hline Malaysia & 4.98 & 8.00 & 7.38 & 8.67 \\
\hline Mexico & 1.50 & 2.64 & 2.85 & 3.12 \\
\hline Nigeria & 1.54 & 1.78 & 2.12 & 2.48 \\
\hline Pakistan & .55 & .55 & .53 & .79 \\
\hline Panama & -.33 & -.69 & -.01 & -.73 \\
\hline Peru & .17 & -.03 & .52 & 1.58 \\
\hline Philippines, the & 1.21 & 1.25 & .52 & 2.02 \\
\hline Portugal & 5.47 & 5.02 & 3.22 & 2.73 \\
\hline Singapore & 19.89 & 16.43 & 20.60 & 19.06 \\
\hline Spain & 4.25 & 3.25 & 2.28 & 1.45 \\
\hline Thailand & 3.09 & 2.35 & 2.27 & 2.78 \\
\hline Turkey & .77 & .90 & .88 & .59 \\
\hline Uruguay & 0 & 0 & .01 & .98 \\
\hline Venezuela & .80 & 3.09 & .93 & .68 \\
\hline
\end{tabular}

Note: FDI flows are normalized by the import price deflator. Percentages are in whole numbers rather than fractions. 
Table 3: Descriptive Statistics

\begin{tabular}{|c|c|c|c|}
\hline Variable & $\begin{array}{l}\text { Low FDI } \\
\text { Countries }\end{array}$ & $\begin{array}{l}\text { High FDI } \\
\text { Countries }\end{array}$ & Source \\
\hline $\begin{array}{l}\text { Real FDI as a Percentage } \\
\text { of GDP (RFDI) }\end{array}$ & .50 & 2.37 & $\begin{array}{l}\text { World Debt Tables } \\
\text { World Bank }\end{array}$ \\
\hline $\begin{array}{l}\text { Real GDP per capita } \\
\text { (GDPCAP) } \\
\text { (hundreds of dollars) }\end{array}$ & $\begin{array}{l}12.89 \\
(.05)\end{array}$ & $\begin{array}{l}23.76 \\
(.45)\end{array}$ & $\begin{array}{l}\text { World Debt Tables } \\
\text { World Bank }\end{array}$ \\
\hline $\begin{array}{l}\text { Annual GDP Growth (percent) } \\
\text { (GDP\%) }\end{array}$ & $\begin{array}{l}3.90 \\
(.10)\end{array}$ & $\begin{array}{l}5.22 \\
(.21)\end{array}$ & $\begin{array}{l}\text { World Debt Tables } \\
\text { World Bank }\end{array}$ \\
\hline $\begin{array}{l}\text { Real Earnings per } \\
\text { Worker }(1970=100) \\
(\text { EARN })\end{array}$ & $\begin{array}{l}132.19 \\
(.06)\end{array}$ & $\begin{array}{l}131.30 \\
(.31)\end{array}$ & $\begin{array}{l}\text { World Debt Tables } \\
\text { World Bank }\end{array}$ \\
\hline $\begin{array}{l}\text { Real Exports as percentage } \\
\text { of GDP (Exports }\end{array}$ & $\begin{array}{l}20.19 \\
(.11)\end{array}$ & $\begin{array}{l}35.00 \\
(.82)\end{array}$ & $\begin{array}{l}\text { World Debt Tables } \\
\text { World Bank }\end{array}$ \\
\hline $\begin{array}{l}\text { Manufacturing Exports } \\
\text { as percentage of GDP (MFEXP) }\end{array}$ & $\begin{array}{l}4.00 \\
(.01)\end{array}$ & $\begin{array}{l}11.51 \\
(.80)\end{array}$ & $\begin{array}{l}\text { World Debt Tables } \\
\text { World Bank }\end{array}$ \\
\hline $\begin{array}{l}\text { Primary Exports } \\
\text { as a percentage of GDP (PPEXP) }\end{array}$ & $\begin{array}{l}9.26 \\
(0.05)\end{array}$ & $\begin{array}{l}10.78 \\
(0.34)\end{array}$ & $\begin{array}{l}\text { World Debt Tables } \\
\text { World Bank }\end{array}$ \\
\hline $\begin{array}{l}\text { Debt Equity } \\
\text { Swaps/Restructuring } \\
\text { as a percentage of Long-Term } \\
\text { Debt (DSWAP) }\end{array}$ & $\begin{array}{l}.25 \\
(.18)\end{array}$ & $\begin{array}{l}.20 \\
(.01)\end{array}$ & $\begin{array}{l}\text { World Debt Tables } \\
\text { World Bank }\end{array}$ \\
\hline $\begin{array}{l}\text { Political Risk } \\
\text { Index (PRI) }\end{array}$ & $\begin{array}{l}43.54 \\
(.15)\end{array}$ & $\begin{array}{l}49.12 \\
(.61)\end{array}$ & BERI, S.A. \\
\hline $\begin{array}{l}\text { Work Days lost as a percentage } \\
\text { of GDP (WDL) }\end{array}$ & $\begin{array}{l}4.30 \\
(-.22)\end{array}$ & $\begin{array}{l}2.20 \\
(-.12)\end{array}$ & ILO Annual Reports \\
\hline Operation Risk Index (ORI) & $\begin{array}{l}43.62 \\
(.05)\end{array}$ & $\begin{array}{l}50.51 \\
(.67)\end{array}$ & BERI, S.A. \\
\hline $\begin{array}{l}\text { Tax on Trade and } \\
\text { Int. Transactions as a percentage } \\
\text { Relative to Tax } \\
\text { Revenue. (ITAX) }\end{array}$ & $\begin{array}{l}17.06 \% \\
(-.09)\end{array}$ & $\begin{array}{l}16.51 \% \\
(-.10)\end{array}$ & $\begin{array}{l}\text { GOVT. FINANCE } \\
\text { STATISTICS, IMF. }\end{array}$ \\
\hline
\end{tabular}

Note: Mean values of the country groupings are on the top line. The Pearson correlation coefficient with RFDI (based on annual observations) is in parenthesis. Percentages are expressed as whole numbers rather than fractions. 
Table 4: Correlation matrix of major variables

\begin{tabular}{|l|l|l|l|l|l|l|l|l|l|l|l|}
\hline & RFDI & GDP\% & GDPCAP & DSWP & EARN & XRATE & EXP. & PRI & WDL & ORI & ITAX \\
\hline RFDI & 1 & & & & & & & & & & \\
\hline GDP\% & .17 & 1 & & & & & & & & & \\
\hline GDPCAP & .57 & -.06 & 1 & & & & & & & & \\
\hline DSWAP & -.02 & .006 & -.03 & 1 & & & & & & & \\
\hline EARN & .11 & .20 & .23 & .02 & 1 & & & & & & \\
\hline XRATE & -.11 & .07 & -.08 & -.02 & .33 & 1 & & & & & \\
\hline EXP. & .86 & .22 & .58 & -.03 & .19 & -.04 & 1 & & & & \\
\hline PRI & .58 & .11 & .67 & -.10 & .18 & .02 & .72 & 1 & & & \\
\hline WDL & -.19 & -.18 & .01 & -.06 & -.11 & -.07 & -.31 & -.24 & 1 & & \\
\hline ORI & .60 & .26 & .60 & -.13 & .23 & -.01 & .71 & .79 & -.14 & 1 & \\
\hline ITAX & -.15 & .31 & -.58 & -.08 & -.13 & -.21 & -.22 & -.41 & .03 & -.24 & 1 \\
\hline
\end{tabular}

Note: Correlation estimates are sensitive to the sample period. The values provided are relevant for the combined Model 3. 
Table 5: FDI and political risk index (PRI)

\begin{tabular}{|c|c|c|c|c|c|}
\hline VARIABLE & Model 1 & Model 2 & Model $3^{2}$ & Model 4 & Model 5 \\
\hline Dep. var. & RFDI & RFDI & RFDI & RFDI & RFDI \\
\hline Constant. & $\begin{array}{l}-1.52 \\
(-3.29)\end{array}$ & $\begin{array}{l}-1.08 \\
(-2.65)\end{array}$ & & & \\
\hline PRI & $\begin{array}{l}.021 \\
(2.67)\end{array}$ & $\begin{array}{l}.019 \\
(2.65)\end{array}$ & $\begin{array}{l}.02 \\
(2.68)\end{array}$ & $\begin{array}{l}.012 \\
(1.40)\end{array}$ & $\begin{array}{l}.02 \\
(2.34)\end{array}$ \\
\hline TIME & $\begin{array}{l}.039 \\
(3.00)\end{array}$ & $\begin{array}{l}.04 \\
(2.50)\end{array}$ & & & \\
\hline GDP\% & $\begin{array}{l}.018 \\
(1.36)\end{array}$ & $\begin{array}{l}.017 \\
(1.91)\end{array}$ & $\begin{array}{l}.017 \\
(1.39)\end{array}$ & $\begin{array}{l}.017 \\
(1.49)\end{array}$ & $\begin{array}{l}.015 \\
(1.19)\end{array}$ \\
\hline GDPCAP & $\begin{array}{l}.0059 \\
(1.41)\end{array}$ & $\begin{array}{l}.00005 \\
(.02)\end{array}$ & $\begin{array}{l}.0006 \\
(.17)\end{array}$ & $\begin{array}{l}.0017 \\
(.52)\end{array}$ & $\begin{array}{l}.0005 \\
(.12)\end{array}$ \\
\hline RFDII & $\begin{array}{l}.89 \\
(13.88)\end{array}$ & $\begin{array}{l}.84 \\
(10.73)\end{array}$ & $\begin{array}{l}.81 \\
(10.26)\end{array}$ & $\begin{array}{l}.74 \\
(9.06)\end{array}$ & $\begin{array}{l}.81 \\
(11.18)\end{array}$ \\
\hline DSWAP & & $\begin{array}{l}.015 \\
(.17)\end{array}$ & $\begin{array}{l}.014 \\
(.15)\end{array}$ & $\begin{array}{l}.016 \\
(.18)\end{array}$ & $\begin{array}{l}.0067 \\
(.07)\end{array}$ \\
\hline EARN & & $\begin{array}{l}-.0017 \\
(-2.66)\end{array}$ & $\begin{array}{l}-.0018 \\
(-2.36)\end{array}$ & $\begin{array}{l}-.0018 \\
(-2.40)\end{array}$ & $\begin{array}{l}-.002 \\
(-2.61)\end{array}$ \\
\hline IPG7 & & & $\begin{array}{l}.024 \\
(3.50)\end{array}$ & $\begin{array}{l}.017 \\
(2.87)\end{array}$ & $\begin{array}{l}.024 \\
(3.63)\end{array}$ \\
\hline XRATE & & & $\begin{array}{l}-.00012 \\
(-2.46)\end{array}$ & $\begin{array}{l}-.00011 \\
(-2.31)\end{array}$ & $\begin{array}{l}-.00012 \\
(-2.29)\end{array}$ \\
\hline DASIA & & & $\begin{array}{l}-2.89 \\
(-3.59)\end{array}$ & $\begin{array}{l}-2.09 \\
(-2.91)\end{array}$ & $\begin{array}{l}-2.75 \\
(-3.61)\end{array}$ \\
\hline DLA & & & $\begin{array}{l}-3.01 \\
(-3.48)\end{array}$ & $\begin{array}{l}-2.09 \\
(-2.74)\end{array}$ & $\begin{array}{l}-2.90 \\
(-3.54)\end{array}$ \\
\hline DAFRICA & & & $\begin{array}{l}-2.77 \\
(-3.10)\end{array}$ & $\begin{array}{l}-1.82 \\
(-2.45)\end{array}$ & $\begin{array}{l}-2.64 \\
(-3.18)\end{array}$ \\
\hline DEUROPE & & & $\begin{array}{l}-2.96 \\
(-3.49)\end{array}$ & $\begin{array}{l}-2.04 \\
(-2.72)\end{array}$ & $\begin{array}{l}-2.88 \\
(-3.58)\end{array}$ \\
\hline EXPORTS & & & & $\begin{array}{l}.015 \\
(2.18)\end{array}$ & \\
\hline $\begin{array}{l}\text { Resid. } \\
\text { Model } 3\end{array}$ & & & & & $\begin{array}{l}.035 \\
(1.78)\end{array}$ \\
\hline F-value & 402.83 & 105.38 & 61.72 & 56.45 & 54.94 \\
\hline D.W. & 2.60 & 2.13 & 2.11 & 2.10 & 2.07 \\
\hline$A d R^{2}$ & .84 & .72 & .72 & .72 & .73 \\
\hline Obs. & 373 & 290 & 257 & 256 & 239 \\
\hline
\end{tabular}

Note: T-values are in parenthesis.

(a) The Alternative Durbin test for Model 3 indicates a t-statistic of -.84 for the lagged error term. 
Table 6: FDI and PRI (Subsample analysis)

\begin{tabular}{|c|c|c|c|c|}
\hline & \multicolumn{2}{|c|}{ Low-FDI Countries" } & \multicolumn{2}{|c|}{ High-FDI Countries ${ }^{b}$} \\
\hline & Model 2 & Model 3 & Model 2 & Model 3 \\
\hline Dep.Var. & RFDl & RFDI & RFDI & RFDI \\
\hline Constant & $\begin{array}{l}-.38 \\
(-1.50)\end{array}$ & & $\begin{array}{l}-2.34 \\
(-2.36)\end{array}$ & \\
\hline PRI & $\begin{array}{l}.0098 \\
(1.83)\end{array}$ & $\begin{array}{l}.01 \\
(1.70)\end{array}$ & $\begin{array}{l}.039 \\
(2.29)\end{array}$ & $\begin{array}{l}.051 \\
(2.48)\end{array}$ \\
\hline TIME & $\begin{array}{l}.016 \\
(1.40)\end{array}$ & & $\begin{array}{l}.07 \\
(2.27)\end{array}$ & \\
\hline GDP\% & $\begin{array}{l}-.0018 \\
(-.17)\end{array}$ & $\begin{array}{l}.0074 \\
(.46)\end{array}$ & $\begin{array}{l}.03 \\
(1.72)\end{array}$ & $\begin{array}{l}.007 \\
(.27)\end{array}$ \\
\hline GDPCAP & $\begin{array}{l}-.0031 \\
(-.73)\end{array}$ & $\begin{array}{l}-.01 \\
(-1.36)\end{array}$ & $\begin{array}{l}-.004 \\
(-.97)\end{array}$ & $\begin{array}{l}.004 \\
(.70)\end{array}$ \\
\hline RFDII & $\begin{array}{l}.58 \\
(5.61)\end{array}$ & $\begin{array}{l}.53 \\
(4.09)\end{array}$ & $\begin{array}{l}.78 \\
(8.33)\end{array}$ & $\begin{array}{l}.71 \\
(6.43)\end{array}$ \\
\hline DSWAP & $\begin{array}{l}5.43 \\
(1.77)\end{array}$ & $\begin{array}{l}3.49 \\
(1.01)\end{array}$ & $\begin{array}{l}.004 \\
(.04)\end{array}$ & $\begin{array}{l}-.02 \\
(-.24)\end{array}$ \\
\hline EARN & $\begin{array}{l}-.00025 \\
(-.36)\end{array}$ & $\begin{array}{l}-.00016 \\
(-.16)\end{array}$ & $\begin{array}{l}-.0011 \\
(-.47)\end{array}$ & $\begin{array}{l}-.0033 \\
(-1.35)\end{array}$ \\
\hline IPG7 & & $\begin{array}{l}.012 \\
(2.25)\end{array}$ & & $\begin{array}{l}.04 \\
(3.12)\end{array}$ \\
\hline XRATE & & $\begin{array}{l}.00001 \\
(.53)\end{array}$ & & $\begin{array}{l}-.0003 \\
(-.58)\end{array}$ \\
\hline DASIA & & $\begin{array}{l}-1.36 \\
(-2.65)\end{array}$ & & $\begin{array}{l}-5.47 \\
(-3.26)\end{array}$ \\
\hline DLA & & $\begin{array}{l}-1.13 \\
(-2.24)\end{array}$ & & $\begin{array}{l}-5.56 \\
(-3.25)\end{array}$ \\
\hline DAFRICA & & $\begin{array}{l}-1.38 \\
(-2.59)\end{array}$ & & $\begin{array}{l}-4.68 \\
(-2.99) \\
\end{array}$ \\
\hline DEUROPE & & $\begin{array}{l}-1.40 \\
(-2.61)\end{array}$ & & $\begin{array}{l}-5.90 \\
(-3.21)\end{array}$ \\
\hline F-Value & 27.20 & 10.82 & 40.11 & 27.61 \\
\hline D.W & 1.95 & 1.95 & 2.13 & 2.03 \\
\hline Obs. & 163 & 130 & 127 & 127 \\
\hline Ad. $R^{2}$ & 0.44 & .45 & 0.68 & .70 \\
\hline
\end{tabular}

Note: PRI Data for each country is for 1978-93, except Bolivia (1979-85), Kenya (1978-85) and China (1986-93).

(a) Low-FDI countries are Argentina, Bolivia, Brazil, Chile, India, Indonesia, Kenya, the Republic of Korea, Pakistan, Peru, Philippines, Turkey, and Venezuela.

(b) High-FDl countries are, China, Colombia, Ecuador, Egypt, Greece, Malaysia, Mexico, Portugal, Spain, and Thailand. 
Table 7: FDI and work days lost (WDL)

\begin{tabular}{|c|c|c|c|c|c|}
\hline Variable & Model 1 & Model 2 & Model 3 & Model 4 & Model 5 \\
\hline Dep Var & RFDI & RFDI & RFDI & RFDI & RFDI \\
\hline Constant. & $\begin{array}{l}-.07 \\
(-.40)\end{array}$ & $\begin{array}{l}-.07 \\
(.39)\end{array}$ & & & \\
\hline WDL & $\begin{array}{l}-.0038 \\
(-.94)\end{array}$ & $\begin{array}{l}-.0072 \\
(-1.32)\end{array}$ & $\begin{array}{l}-.0097 \\
(-1.56)\end{array}$ & $\begin{array}{l}.0017 \\
(.26)\end{array}$ & $\begin{array}{l}-012 \\
(-1.7))\end{array}$ \\
\hline TIME & $\begin{array}{l}.01 \\
(1.86)\end{array}$ & $\begin{array}{l}.016 \\
(1.79)\end{array}$ & & & \\
\hline GDP\% & $\begin{array}{l}.008 \\
(.69)\end{array}$ & $\begin{array}{l}.02 \\
(1.49)\end{array}$ & $\begin{array}{l}.014 \\
(.91)\end{array}$ & $\begin{array}{l}.01 \\
(.61)\end{array}$ & $\begin{array}{l}.011 \\
(.70)\end{array}$ \\
\hline GDPCAP & $\begin{array}{l}.005 \\
(2.85)\end{array}$ & $\begin{array}{l}.011 \\
(2.11)\end{array}$ & $\begin{array}{l}.015 \\
(2.57)\end{array}$ & $\begin{array}{l}-.0036 \\
(-.49)\end{array}$ & $\begin{array}{l}.016 \\
(2.67)\end{array}$ \\
\hline RFDI1 & $\begin{array}{l}.82 \\
(17.35)\end{array}$ & $\begin{array}{l}.87 \\
(13.29)\end{array}$ & $\begin{array}{l}.84 \\
(12.76)\end{array}$ & $\begin{array}{l}.76 \\
(11.57)\end{array}$ & $\begin{array}{l}.83 \\
(11.85)\end{array}$ \\
\hline DSWAP & & $\begin{array}{l}.021 \\
(2.27)\end{array}$ & $\begin{array}{l}.025 \\
(2.46)\end{array}$ & $\begin{array}{l}.02 \\
(2.51)\end{array}$ & $\begin{array}{l}.02 \\
(2.43)\end{array}$ \\
\hline EARN & & $\begin{array}{l}-.0014 \\
(-2.46)\end{array}$ & $\begin{array}{l}-.0019 \\
(-2.26)\end{array}$ & $\begin{array}{l}-.0009 \\
(-1.20)\end{array}$ & $\begin{array}{l}-.0021 \\
(-2.5)\end{array}$ \\
\hline IPG7 & & & $\begin{array}{l}.013 \\
(2.50)\end{array}$ & $\begin{array}{l}.011 \\
(2.51)\end{array}$ & $\begin{array}{l}.015 \\
(2.91)\end{array}$ \\
\hline XRATE & & & $\begin{array}{l}-.00006 \\
(-.99)\end{array}$ & $\begin{array}{l}-.00017 \\
(-2.17)\end{array}$ & $\begin{array}{l}-.00007 \\
(-1.1)\end{array}$ \\
\hline DASIA & & & $\begin{array}{l}-1.06 \\
(-1.86)\end{array}$ & $\begin{array}{l}-1.44 \\
(-2.67)\end{array}$ & $\begin{array}{l}-1.32 \\
(-2.14)\end{array}$ \\
\hline DLA & & & $\begin{array}{l}-1.35 \\
(-2.16)\end{array}$ & $\begin{array}{l}-1.59 \\
(-2.70)\end{array}$ & $\begin{array}{l}-1.68 \\
(-2.49)\end{array}$ \\
\hline DAFRICA & & & $\begin{array}{l}-1.08 \\
(-1.92)\end{array}$ & $\begin{array}{l}-1.42 \\
(-2.54)\end{array}$ & $\begin{array}{l}-1.27 \\
(-2.1)\end{array}$ \\
\hline DEUROPE & & & $\begin{array}{l}-1.22 \\
(-2.18)\end{array}$ & $\begin{array}{l}-1.21 \\
(-2.39)\end{array}$ & $\begin{array}{l}-1.49 \\
(-2.52)\end{array}$ \\
\hline EXPORTS & & & & $\begin{array}{l}.019 \\
(2.55)\end{array}$ & \\
\hline $\begin{array}{l}\text { Resid. } \\
\text { Model } 3\end{array}$ & & & & & $\begin{array}{l}.18 \\
(.12)\end{array}$ \\
\hline F-value & 161.67 & 96.95 & 57.24 & 53.63 & 49.70 \\
\hline D.W. & 2.22 & 2.08 & 2.11 & 2.10 & 2.04 \\
\hline Ad. $R$ & .69 & .73 & .72 & .73 & .72 \\
\hline Obs. & 368 & 248 & 238 & 237 & 225 \\
\hline
\end{tabular}

Note: T-values are in parenthesis. Models are reported after first-order autocorrelation correction. Most countries have missing observations - data where available are from 1972-92. See notes on table 8 for the list of countries. 
Table 8: FDI and WDL (sub-sample analysis)

\begin{tabular}{|c|c|c|c|c|}
\hline \multirow[b]{2}{*}{ Variable } & \multicolumn{2}{|c|}{ Low FDI countries" } & \multicolumn{2}{|c|}{ High-FDI countries ${ }^{b .}$} \\
\hline & MODEL 2 & MODEL 3 & MODEL 2 & MODEL 3 \\
\hline Dep.var. & RFDI & RFDI & RFDI & RFDI \\
\hline Constant & $\begin{array}{l}.23 \\
(1.42)\end{array}$ & & $\begin{array}{l}-.53 \\
(-1.06)\end{array}$ & \\
\hline WDL & $\begin{array}{l}-.011 \\
(-2.30)\end{array}$ & $\begin{array}{l}-.0089 \\
(-1.76)\end{array}$ & $\begin{array}{l}-.07 \\
(-1.11)\end{array}$ & $\begin{array}{l}.024 \\
(.33)\end{array}$ \\
\hline Time & $\begin{array}{l}.004 \\
(.57)\end{array}$ & & $\begin{array}{l}.02 \\
(1.27)\end{array}$ & \\
\hline GDP\% & $\begin{array}{l}-.01 \\
(-.72)\end{array}$ & $\begin{array}{l}-.01 \\
(-.61)\end{array}$ & $\begin{array}{l}.072 \\
(3.19)\end{array}$ & $\begin{array}{l}.06 \\
(2.38)\end{array}$ \\
\hline GDPCAP & $\begin{array}{l}-.005 \\
(-.82)\end{array}$ & $\begin{array}{l}-.009 \\
(-1.69)\end{array}$ & $\begin{array}{l}.026 \\
(2.68)\end{array}$ & $\begin{array}{l}.010 \\
(2.80)\end{array}$ \\
\hline RFDI1 & $\begin{array}{l}.51 \\
(4.49)\end{array}$ & $\begin{array}{l}.46 \\
(4.06)\end{array}$ & $\begin{array}{l}.82 \\
(10.61)\end{array}$ & $\begin{array}{l}.67 \\
(6.65)\end{array}$ \\
\hline DSWAP & $\begin{array}{l}5.18 \\
(1.64)\end{array}$ & $\begin{array}{l}4.34 \\
(1.08)\end{array}$ & $\begin{array}{l}.024 \\
(2.40)\end{array}$ & $\begin{array}{l}.02 \\
(1.88)\end{array}$ \\
\hline EARN & $\begin{array}{l}.00064 \\
(.96)\end{array}$ & $\begin{array}{l}.0009 \\
(1.02)\end{array}$ & $\begin{array}{l}-.0012 \\
(-.51)\end{array}$ & $\begin{array}{l}-.0014 \\
(-.62)\end{array}$ \\
\hline IPG7 & & $\begin{array}{l}.00068 \\
(.13)\end{array}$ & & $\begin{array}{l}.005 \\
(.59)\end{array}$ \\
\hline XRATE & & $\begin{array}{l}.00008 \\
(1.68)\end{array}$ & & $\begin{array}{l}.00042 \\
(.68)\end{array}$ \\
\hline DASIA & & $\begin{array}{l}.14 \\
(.27)\end{array}$ & & $\begin{array}{l}-1.48 \\
(-1.44)\end{array}$ \\
\hline DLA & & $\begin{array}{l}.39 \\
(.69)\end{array}$ & & $\begin{array}{l}-2.22 \\
(-2.00)\end{array}$ \\
\hline DAFRICA & & $\begin{array}{l}.27 \\
(.49)\end{array}$ & & $\begin{array}{l}-.92 \\
(-.91)\end{array}$ \\
\hline DEUROPE & & $\begin{array}{l}.16 \\
.31\end{array}$ & & $\begin{array}{l}-4.27 \\
(-2.94)\end{array}$ \\
\hline F-value & 12.71 & 7.20 & 35.59 & 23.71 \\
\hline D.W & 2.11 & 2.12 & 2.07 & 2.02 \\
\hline Obs. & 151 & 141 & 97 & 97 \\
\hline Ad. $R^{2}$ & 0.35 & .32 & 0.72 & 0.72 \\
\hline
\end{tabular}

Note: T-values are in parentheses.

(a) Low-FDI countries are Chile, India, Indonesia. Kenya, the Republic of Korea, Pakistan, Panama, Peru, the Philippines, Turkey.

(b) High-FDI countries are Costa Rica Ecuador, Egypt, Malaysia, Mexico, Portugal, and Thailand. Most countries have missing observations. Data availability varies for each country where available, data is from 1972-92. 
Table 9: FDI and operation risk index (ORI)

\begin{tabular}{|c|c|c|c|c|c|}
\hline Variable & Model 1 & Model 2 & Model 3 & Model 4 & Model 5 \\
\hline Dep.var. & RFDI & RFDI & RFDI & RFDI & RFDI \\
\hline Constant. & $\begin{array}{l}-1.26 \\
(-3.45)\end{array}$ & $\begin{array}{l}-.72 \\
(-2.81)\end{array}$ & & & \\
\hline ORI & $\begin{array}{l}.022 \\
(3.01)\end{array}$ & $\begin{array}{l}.019 \\
(3.28)\end{array}$ & $\begin{array}{l}.019 \\
(3.23)\end{array}$ & $\begin{array}{l}.007 \\
(1.19)\end{array}$ & $\begin{array}{l}.016 \\
(2.30)\end{array}$ \\
\hline Time & $\begin{array}{l}.028 \\
(2.93)\end{array}$ & $\begin{array}{l}.03 \\
(2.76)\end{array}$ & & & \\
\hline GDPCAP & $\begin{array}{l}.009 \\
(2.32)\end{array}$ & $\begin{array}{l}.0017 \\
(.81)\end{array}$ & $\begin{array}{l}.005 \\
(1.17)\end{array}$ & $\begin{array}{l}.0038 \\
(.95)\end{array}$ & $\begin{array}{l}.0015 \\
(.35)\end{array}$ \\
\hline RFDI1 & $\begin{array}{l}.83 \\
(12.83)\end{array}$ & $\begin{array}{l}.65 \\
(6.32)\end{array}$ & $\begin{array}{l}.61 \\
(5.82)\end{array}$ & $\begin{array}{l}.52 \\
(5.17)\end{array}$ & $\begin{array}{l}.76 \\
(9.30)\end{array}$ \\
\hline DSWAP & & $\begin{array}{l}.047 \\
(.60)\end{array}$ & $\begin{array}{l}.04 \\
(.50)\end{array}$ & $\begin{array}{l}.039 \\
(.51)\end{array}$ & $\begin{array}{l}.02 \\
(.27)\end{array}$ \\
\hline EARN & & $\begin{array}{l}-.0017 \\
(-2.85)\end{array}$ & $\begin{array}{l}-.0018 \\
(-2.55)\end{array}$ & $\begin{array}{l}-.0021 \\
(-2.84)\end{array}$ & $\begin{array}{l}-.0014 \\
(-2.0)\end{array}$ \\
\hline IPG7 & & & $\begin{array}{l}.018 \\
(3.08)\end{array}$ & $\begin{array}{l}.013 \\
(2.40)\end{array}$ & $\begin{array}{l}.022 \\
(3.33)\end{array}$ \\
\hline XRATE & & & $\begin{array}{l}-.0001 \\
(-1.81)\end{array}$ & $\begin{array}{l}-.00014 \\
(-2.17)\end{array}$ & $\begin{array}{l}-.00012 \\
(-2.1)\end{array}$ \\
\hline DASIA & & & $\begin{array}{l}-1.89 \\
(-3.45)\end{array}$ & $\begin{array}{l}-1.44 \\
(-2.82)\end{array}$ & $\begin{array}{l}-2.38 \\
(-3.6)\end{array}$ \\
\hline DLA & & & $\begin{array}{l}-1.98 \\
(-3.33)\end{array}$ & $\begin{array}{l}-1.40 \\
(-2.49)\end{array}$ & $\begin{array}{l}-2.58 \\
(-3.44)\end{array}$ \\
\hline DAFRICA & & & $\begin{array}{l}-1.53 \\
(-2.41)\end{array}$ & $\begin{array}{l}-.97 \\
(-1.66)\end{array}$ & $\begin{array}{l}-2.12 \\
(-2.72)\end{array}$ \\
\hline DEUROPE & & & $\begin{array}{l}-1.99 \\
(-3.97)\end{array}$ & $\begin{array}{l}-1.33 \\
(-2.82)\end{array}$ & $\begin{array}{l}-2.37 \\
(-3.8)\end{array}$ \\
\hline EXPORTS & & & & $\begin{array}{l}.027 \\
(3.50)\end{array}$ & \\
\hline $\begin{array}{l}\text { Residual } \\
\text { Model } 3\end{array}$ & & & & & $\begin{array}{l}.014 \\
(.58)\end{array}$ \\
\hline F-value & 451.39 & 76.09 & 41.77 & 43.53 & 52.08 \\
\hline D.W. & 2.30 & 1.82 & 1.80 & 1.82 & 1.96 \\
\hline Ad. $R^{2}$ & .80 & .56 & .57 & .60 & .66 \\
\hline Obs. & 443 & 351 & 308 & 307 & 290 \\
\hline
\end{tabular}

Note: T-values are in parenthesis.

(a) The alternative Durbin Statistic for Model 3 indicates a t-statistic of 0.52 for the lagged error term. For list of countries and data availability, see the notes in table 10. 
Table 10: FDI and ORI (sub-sample analysis)

\begin{tabular}{|c|c|c|c|c|}
\hline \multirow{2}{*}{ Variable } & \multicolumn{2}{|c|}{ Low FDI countries". } & \multicolumn{2}{|c|}{ High-FDI countries ${ }^{b}$} \\
\hline & Model 2 & Model 3 & Model 2 & Model 3 \\
\hline Dep.var. & RFDI & RFDI & RFDI & RFDI \\
\hline Constant & $\begin{array}{l}.13 \\
(.62)\end{array}$ & & $\begin{array}{l}-1.22 \\
(-1.85)\end{array}$ & \\
\hline ORI & $\begin{array}{l}.0062 \\
(1.19)\end{array}$ & $\begin{array}{l}.008 \\
(1.04)\end{array}$ & $\begin{array}{l}.02 \\
(1.84)\end{array}$ & $\begin{array}{l}.018 \\
(1.88)\end{array}$ \\
\hline Time & $\begin{array}{l}.003 \\
(.24)\end{array}$ & & $\begin{array}{l}.045 \\
(2.45)\end{array}$ & \\
\hline GDPCAP & $\begin{array}{l}-.0037 \\
(-.77)\end{array}$ & $\begin{array}{l}-.02 \\
(-1.56)\end{array}$ & $\begin{array}{l}-.0011 \\
(-.39)\end{array}$ & $\begin{array}{l}.002 \\
(.28)\end{array}$ \\
\hline RFDI1 & $\begin{array}{l}.19 \\
(1.72)\end{array}$ & $\begin{array}{l}.12 \\
(1.12)\end{array}$ & $\begin{array}{l}.75 \\
(7.86)\end{array}$ & $\begin{array}{l}.68 \\
(7.23)\end{array}$ \\
\hline DSWAP & $\begin{array}{l}7.77 \\
(2.06)\end{array}$ & $\begin{array}{l}5.71 \\
(1.35)\end{array}$ & $\begin{array}{l}.003 \\
(.04)\end{array}$ & $\begin{array}{l}-.03 \\
(-.32)\end{array}$ \\
\hline EARN & $\begin{array}{l}.00002 \\
(.03)\end{array}$ & $\begin{array}{l}.0008 \\
(.79)\end{array}$ & $\begin{array}{l}.0005 \\
(.22)\end{array}$ & $\begin{array}{l}-.0023 \\
(-1.09)\end{array}$ \\
\hline IPG7 & & $\begin{array}{l}.0057 \\
(.71)\end{array}$ & & $\begin{array}{l}.03 \\
(3.83)\end{array}$ \\
\hline XRATE & & $\begin{array}{l}.00009 \\
(2.15)\end{array}$ & & $\begin{array}{l}-.0011 \\
(-2.14)\end{array}$ \\
\hline DASIA & & $\begin{array}{l}-.59 \\
(-.79)\end{array}$ & & $\begin{array}{l}-3.01 \\
(-3.36)\end{array}$ \\
\hline DLA & & $\begin{array}{l}-.12 \\
(-.16)\end{array}$ & & $\begin{array}{l}-3.27 \\
(-3.82)\end{array}$ \\
\hline DAFRICA & & $\begin{array}{l}-.16 \\
(-.21)\end{array}$ & & $\begin{array}{l}-2.73 \\
(-2.74)\end{array}$ \\
\hline DEUROPE & & $\begin{array}{l}-.63 \\
(-.90)\end{array}$ & & $\begin{array}{l}-3.15 \\
(-3.88)\end{array}$ \\
\hline F-value & 4.94 & 3.60 & 49.78 & 32.71 \\
\hline D.W & 1.58 & 1.57 & 1.93 & 1.94 \\
\hline Obs. & 200 & 157 & 151 & 151 \\
\hline Adj. $R^{2}$ & 0.11 & .14 & 0.66 & .68 \\
\hline
\end{tabular}

Note: $T$-values are in parenthesis.

(a) Low-FDI countries are Argentina, Bolivia, Brazil. Chile, India, Indonesia, Kenya, the Republic of Korea, Pakistan, Peru, Philippines, Turkey, and Venezuela.

(b) High-FDI countries are Ecuador, China, Colombia, Egypt, Greece, Malaysia, Mexico, Nigeria, Portugal, Singapore, Spain, and Thailand. ORI data for each country spans 1975-93, except for Bolivia and Kenya (1975-85) and China (1986-93). 
Table 11: FDI and taxes on international trade (ITAX)

\begin{tabular}{|c|c|c|c|c|c|}
\hline Variable & Model 1 & Model 2 & Model 3 & Model 4 & Model 5 \\
\hline Dep. var. & RFDI & RFDI & RFDI & RFDI & RFDI \\
\hline Constant & $\begin{array}{l}.65 \\
(2.04)\end{array}$ & $\begin{array}{l}-.82 \\
(-2.89)\end{array}$ & & & \\
\hline ITAX & $\begin{array}{l}-.02 \\
(-1.40)\end{array}$ & $\begin{array}{l}.011 \\
(2.73)\end{array}$ & $\begin{array}{l}.015 \\
(3.17)\end{array}$ & $\begin{array}{l}.012 \\
(2.23)\end{array}$ & $\begin{array}{l}.01 \\
(1.81)\end{array}$ \\
\hline Time & $\begin{array}{l}.09 \\
(4.01)\end{array}$ & $\begin{array}{l}.012 \\
(1.45)\end{array}$ & $\begin{array}{l}.013 \\
(1.50)\end{array}$ & & \\
\hline GDPCAP & & $\begin{array}{l}.0078 \\
(2.93)\end{array}$ & $\begin{array}{l}.0053 \\
(1.79)\end{array}$ & $\begin{array}{l}.007 \\
(2.13)\end{array}$ & $\begin{array}{l}.006 \\
(1.98)\end{array}$ \\
\hline GDP\% & & $\begin{array}{l}.004 \\
(.24)\end{array}$ & $\begin{array}{l}.007 \\
(.40)\end{array}$ & $\begin{array}{l}.006 \\
(.28)\end{array}$ & $\begin{array}{l}.0028 \\
(.13)\end{array}$ \\
\hline EXPORTS & & $\begin{array}{l}.019 \\
(3.88)\end{array}$ & $\begin{array}{l}.024 \\
(4.43)\end{array}$ & $\begin{array}{l}.024 \\
(4.51)\end{array}$ & $\begin{array}{l}.024 \\
(4.51)\end{array}$ \\
\hline RFDI1 & & $\begin{array}{l}.73 \\
(10.91)\end{array}$ & $\begin{array}{l}.71 \\
(10.11)\end{array}$ & $\begin{array}{l}.66 \\
(8.66)\end{array}$ & $\begin{array}{l}.67 \\
(8.80)\end{array}$ \\
\hline EARN & & & & $\begin{array}{l}-.0015 \\
(-1.95)\end{array}$ & $\begin{array}{l}-.002 \\
(-1.99)\end{array}$ \\
\hline IPG7 & & & & $\begin{array}{l}.014 \\
(2.63)\end{array}$ & $\begin{array}{l}.014 \\
(2.61)\end{array}$ \\
\hline XRATE & & & & $\begin{array}{l}-.00007 \\
(-1.72)\end{array}$ & $\begin{array}{l}-.00008 \\
(-1.8)\end{array}$ \\
\hline DASIA & & & $\begin{array}{l}-1.14 \\
(-3.56)\end{array}$ & $\begin{array}{l}-2.12 \\
(-3.07)\end{array}$ & $\begin{array}{l}-2.01 \\
(-2.95)\end{array}$ \\
\hline DLA & & & $\begin{array}{l}-.95 \\
(-3.05)\end{array}$ & $\begin{array}{l}-2.09 \\
(-2.95)\end{array}$ & $\begin{array}{l}-2.01 \\
(-2.88)\end{array}$ \\
\hline DAFRICA & & & $\begin{array}{l}-.52 \\
(-1.04)\end{array}$ & $\begin{array}{l}-1.36 \\
(-1.59)\end{array}$ & $\begin{array}{l}-1.23 \\
(-1.47)\end{array}$ \\
\hline DEUROPE & & & $\begin{array}{l}-.73 \\
(-2.91)\end{array}$ & $\begin{array}{l}-1.84 \\
(-2.99)\end{array}$ & $\begin{array}{l}-1.75 \\
(-2.88)\end{array}$ \\
\hline $\begin{array}{l}\text { Residual } \\
\text { Model } 3\end{array}$ & & & & & $\begin{array}{l}.02 \\
(1.37)\end{array}$ \\
\hline F-value & 11.03 & 384.92 & 259.40 & 187.84 & 172.49 \\
\hline D.W. & .18 & 2.23 & 2.21 & 2.22 & 2.22 \\
\hline Ad. $R^{2}$ & .05 & .86 & .86 & .86 & .86 \\
\hline Obs. & 374 & 363 & 363 & 320 & 320 \\
\hline
\end{tabular}

Note: T-values are in parenthesis. The models are corrected for first-order autocorrelation. See notes of table 9 for information about countries included in the sample. 
Table 12: FDI and ITAX (sub-sample analysis)

\begin{tabular}{|c|c|c|c|c|}
\hline \multirow{2}{*}{ Variable } & \multicolumn{2}{|c|}{ Low-FDI countries" } & \multicolumn{2}{|c|}{ High-FDI countries ${ }^{b}$} \\
\hline & Model 3 & Model 4 & Model 3 & Model 4 \\
\hline Dep.var. & RFDI & RFDI & RFDI & RFDI \\
\hline ITAX & $\begin{array}{l}-.01 \\
(-1.74)\end{array}$ & $\begin{array}{l}-.0068 \\
(-1.06)\end{array}$ & $\begin{array}{l}.023 \\
(2.10)\end{array}$ & $\begin{array}{l}.03 \\
(2.11)\end{array}$ \\
\hline TIME & $\begin{array}{l}.018 \\
(1.58)\end{array}$ & & $\begin{array}{l}.04 \\
(3.27)\end{array}$ & \\
\hline GDPCAP & $\begin{array}{l}-.008 \\
(-1.16)\end{array}$ & $\begin{array}{l}-.01 \\
(-.96)\end{array}$ & $\begin{array}{l}.01 \\
(2.05)\end{array}$ & $\begin{array}{l}.011 \\
(2.39)\end{array}$ \\
\hline GDPGROW & $\begin{array}{l}.012 \\
(.64)\end{array}$ & $\begin{array}{l}.016 \\
(.85)\end{array}$ & $\begin{array}{l}.05 \\
(2.35)\end{array}$ & $\begin{array}{l}.032 \\
(1.26)\end{array}$ \\
\hline RFDI1 & $\begin{array}{l}.40 \\
(3.29)\end{array}$ & $\begin{array}{l}.35 \\
(3.00)\end{array}$ & $\begin{array}{l}.69 \\
(7.87)\end{array}$ & $\begin{array}{l}.67 \\
(6.77)\end{array}$ \\
\hline EARN & & $\begin{array}{l}.0013 \\
(1.06)\end{array}$ & & $\begin{array}{l}-.0025 \\
(-.74)\end{array}$ \\
\hline EXPORTS & $\begin{array}{l}.0002 \\
(.02)\end{array}$ & $\begin{array}{l}-.0024 \\
(-.19)\end{array}$ & $\begin{array}{l}.023 \\
(4.42)\end{array}$ & $\begin{array}{l}.025 \\
(4.57)\end{array}$ \\
\hline IPG7 & & $\begin{array}{l}.0035 \\
(.39)\end{array}$ & & $\begin{array}{l}.034 \\
(3.80)\end{array}$ \\
\hline XRATE & & $\begin{array}{l}.00005 \\
(.69)\end{array}$ & & $\begin{array}{l}-.0029 \\
(-2.16)\end{array}$ \\
\hline DASIA & $\begin{array}{l}.23 \\
(.49)\end{array}$ & $\begin{array}{l}-.27 \\
(-.25)\end{array}$ & $\begin{array}{l}-2.10 \\
(-3.74)\end{array}$ & $\begin{array}{l}-5.00 \\
(-3.90)\end{array}$ \\
\hline DLA & $\begin{array}{l}.43 \\
(.75)\end{array}$ & $\begin{array}{l}.23 \\
(.17)\end{array}$ & $\begin{array}{l}-1.49 \\
(-3.68)\end{array}$ & $\begin{array}{l}-4.25 \\
(-3.93)\end{array}$ \\
\hline DAFRICA & & & $\begin{array}{l}-1.51 \\
(-2.36)\end{array}$ & $\begin{array}{l}-4.24 \\
(-3.13)\end{array}$ \\
\hline DEUROPE & $\begin{array}{l}.16 \\
(.65)\end{array}$ & $\begin{array}{l}-.22 \\
(-.22)\end{array}$ & $\begin{array}{l}-1.53 \\
(-3.99)\end{array}$ & $\begin{array}{l}-4.00 \\
(-4.13)\end{array}$ \\
\hline F-value & 6.27 & 3.68 & 194.22 & 145.76 \\
\hline D.W. & 2.19 & 2.20 & 2.11 & 2.15 \\
\hline Obs. & 172 & 151 & 191 & 169 \\
\hline Ad. $R^{2}$ & 0.05 & .02 & 0.90 & .90 \\
\hline
\end{tabular}

Note: $\quad T$-values are in parenthesis.

(a) Low-FDI countries are Chile, India, Indonesia, the Republic of Korea, Pakistan, Panama, Turkey, Uruguay.

(b) High-FDI countries are Colombia, Costa Rica, Egypt, Greece, Malaysia, Mexico, Portugal, Spain, and Thailand. Most countries have missing observations. Available data spans form 1972-93. The models are corrected for first-order autocorrelation. 
Table 13: Exports in low and high-FDI countries

\begin{tabular}{|c|c|c|c|c|c|c|}
\hline \multirow[b]{2}{*}{ Variable } & \multicolumn{2}{|l|}{ Exports } & \multicolumn{2}{|c|}{ Manuf. Exports } & \multicolumn{2}{|c|}{ Primary Exports } \\
\hline & $\begin{array}{l}\text { High-FDI } \\
\text { Countries }\end{array}$ & $\begin{array}{l}\text { Low-FDI } \\
\text { Countries }\end{array}$ & $\begin{array}{l}\text { High-FDI } \\
\text { Countries }\end{array}$ & $\begin{array}{l}\text { Low-FDI } \\
\text { Countries }\end{array}$ & $\begin{array}{l}\text { High-FDI } \\
\text { Countries }\end{array}$ & $\begin{array}{l}\text { Low-FDI } \\
\text { Countries }\end{array}$ \\
\hline EXPORTS & $\begin{array}{l}.02 \\
(4.62)\end{array}$ & $\begin{array}{l}.0046 \\
(.87)\end{array}$ & & & & \\
\hline MFEXP $^{\mathrm{a}}$ & & & $\begin{array}{l}.039 \\
(4.80)\end{array}$ & $\begin{array}{l}.009 \\
(.82)\end{array}$ & & \\
\hline PPEXP & & & & & $\begin{array}{l}.019 \\
(1.34)\end{array}$ & $\begin{array}{l}.0053 \\
(.27)\end{array}$ \\
\hline GDPCAP & $\begin{array}{l}.013 \\
(2.78)\end{array}$ & $\begin{array}{l}-.009 \\
(-1.48)\end{array}$ & $\begin{array}{l}.006 \\
(1.30)\end{array}$ & $\begin{array}{l}-.01 \\
(-1.43)\end{array}$ & $\begin{array}{l}.033 \\
(2.45)\end{array}$ & $\begin{array}{l}-.008 \\
(-1.31)\end{array}$ \\
\hline GDP\% & $\begin{array}{l}-.004 \\
(-.17)\end{array}$ & $\begin{array}{l}.008 \\
(.68)\end{array}$ & $\begin{array}{l}.01 \\
(.44)\end{array}$ & $\begin{array}{l}.009 \\
(.78)\end{array}$ & $\begin{array}{l}-.0034 \\
(-.12)\end{array}$ & $\begin{array}{l}.01 \\
(.79)\end{array}$ \\
\hline RFDI1 & $\begin{array}{l}.63 \\
(9.50)\end{array}$ & $\begin{array}{l}.25 \\
(2.96)\end{array}$ & $\begin{array}{l}.63 \\
(10.20)\end{array}$ & $\begin{array}{l}.22 \\
(2.82)\end{array}$ & $\begin{array}{l}. .74 \\
(5.71)\end{array}$ & $\begin{array}{l}.22 \\
(2.77)\end{array}$ \\
\hline EARN & $\begin{array}{l}.0002 \\
(.08)\end{array}$ & $\begin{array}{l}.0011 \\
(1.40)\end{array}$ & $\begin{array}{l}-.0009 \\
(-.42)\end{array}$ & $\begin{array}{l}.001 \\
(1.35)\end{array}$ & $\begin{array}{l}.0013 \\
(.42)\end{array}$ & $\begin{array}{l}.0012 \\
(1.55)\end{array}$ \\
\hline IPG7 & $\begin{array}{l}.019 \\
(2.94)\end{array}$ & $\begin{array}{l}.0003 \\
(.05)\end{array}$ & $\begin{array}{l}.02 \\
(4.23)\end{array}$ & $\begin{array}{l}.0014 \\
(.26)\end{array}$ & $\begin{array}{l}.019 \\
(2.29)\end{array}$ & $\begin{array}{l}.0026 \\
(.50)\end{array}$ \\
\hline DASIA & $\begin{array}{l}-2.32 \\
(-2.89)\end{array}$ & $\begin{array}{l}.01 \\
(.04)\end{array}$ & $\begin{array}{l}-1.94 \\
(-2.69)\end{array}$ & $\begin{array}{l}-.04 \\
(-.09)\end{array}$ & $\begin{array}{l}-1.94 \\
(-2.63)\end{array}$ & $\begin{array}{l}-.16 \\
(-.35)\end{array}$ \\
\hline DEUROPE & $\begin{array}{l}-2.51 \\
(-3.59)\end{array}$ & $\begin{array}{l}.36 \\
(.77)\end{array}$ & $\begin{array}{l}-2.16 \\
(-3.56)\end{array}$ & $\begin{array}{l}.39 \\
(.69)\end{array}$ & $\begin{array}{l}-2.26 \\
(-2.54)\end{array}$ & $\begin{array}{l}.14 \\
(.26)\end{array}$ \\
\hline DAFRICA & $\begin{array}{l}-1.94 \\
(-2.56)\end{array}$ & $\begin{array}{l}.06 \\
(.15)\end{array}$ & $\begin{array}{l}-1.48 \\
(-2.09)\end{array}$ & $\begin{array}{l}.19 \\
(.37)\end{array}$ & $\begin{array}{l}-1.67 \\
(-2.07)\end{array}$ & $\begin{array}{l}.01 \\
(.02)\end{array}$ \\
\hline DLAMERICA & $\begin{array}{l}-2.95 \\
(-4.26)\end{array}$ & $\begin{array}{l}.08 \\
(.21)\end{array}$ & $\begin{array}{l}-2.41 \\
(-4.08)\end{array}$ & $\begin{array}{l}.04 \\
(.10)\end{array}$ & $\begin{array}{l}-3.28 \\
(-2.71)\end{array}$ & $\begin{array}{l}-.12 \\
(-.25)\end{array}$ \\
\hline Ad. $R^{2}$ & .89 & .10 & .90 & .08 & .81 & .08 \\
\hline F-value & 192.67 & 4.94 & 215.28 & 3.84 & 107.15 & 3.82 \\
\hline Obs. & 203 & 305 & 202 & 290 & 213 & 290 \\
\hline D. Watson & 1.81 & 2.11 & 1.89 & 2.14 & 2.27 & 2.14 \\
\hline
\end{tabular}

Note: T-values are in parenthesis. The models for high-FDI countries (with EXPORTS and MFEXP) are reported after correcting for first-order autocorrelation.

(a) Share of GDP. 
Table 14: Causality tests for exports

(high-FDI countries)

\begin{tabular}{|c|c|c|}
\hline \multicolumn{3}{|c|}{ Causality tests for general exports } \\
\hline Country & $\begin{array}{l}\text { F-test value } \\
\text { (exports to FDI) }\end{array}$ & $\begin{array}{l}\text { F-test value } \\
\text { (FDI to exports) }\end{array}$ \\
\hline Colombia & .71 & 1.03 \\
\hline Costa Rica & 2.28 & 1.07 \\
\hline Ecuador & $4.40^{b}$ & 1.01 \\
\hline Egypt & .85 & 1.38 \\
\hline Greece & $2.73^{\mathrm{a}}$ & 1.29 \\
\hline Malaysia & 2.47 & .96 \\
\hline Mexico & 1.42 & 0.98 \\
\hline Nigeria & 1.94 & 0.40 \\
\hline Portugal & $4.53^{b}$ & 0.95 \\
\hline Singapore & $2.86^{\mathrm{n}}$ & $3.67^{\text {a. }}$ \\
\hline Spain & 0.28 & 0.26 \\
\hline Thailand & $8.46^{\mathrm{c}}$ & 1.33 \\
\hline $\begin{array}{l}\text { Pooled model } \\
\text { (Ecuador, Malaysia, } \\
\text { Portugal, Thailand) }\end{array}$ & $19.21^{\mathrm{c}}$ & $4.16^{b}$ \\
\hline \multicolumn{3}{|c|}{ Causality Tests for Manufacturing Exports } \\
\hline Country & $\begin{array}{l}\text { F-value } \\
\text { Manuf. Exp. to FDI }\end{array}$ & $\begin{array}{l}\text { F-value } \\
\text { FDI to Mauf. Exp. }\end{array}$ \\
\hline Ecuador & $7.12^{\mathrm{c}}$ & 1.17 \\
\hline Greece & $2.80^{\mathrm{a}}$ & 2.38 \\
\hline Portugal & $9.10^{c}$ & .93 \\
\hline Singapore & $5.63^{b}$ & $3.61^{\mathrm{a}}$ \\
\hline Thailand & 2.30 & 0.17 \\
\hline $\begin{array}{l}\text { Pooled model for } \\
\text { five countries }\end{array}$ & $26.46^{\mathrm{c}}$ & $2.78^{\circ}$ \\
\hline
\end{tabular}

Note. The individual country and combined tests include three lags. The individual country results should be interpreted with caution, because of the small sample size. Botswana and China are high-FDI countries that could not be analyzed because of an incomplete data set.
(a) Significant at 1 percent level.
(b) Significant at 5 percent level
(c) Significant at 10 percent level 


\section{Appendix II}

\section{Methodological note}

Three approaches were employed to analyze the determinants of FDI flows.

\section{Micro-oriented econometric studies}

These studies are conducted at the firm or industry level, particularly in industries that are regarded as "foot-loose," such as electronics. Since the decision to invest is a corporate-level decision, these disaggregate studies are useful for capturing the complexity of industry-specific determinants of FDI flows. But, although most studies employ a dependent variable that is sector-specific (usually at a two-or three-digit SIC code), the explanatory variables have countryspecific dimensions.

For example, Woodward and Rolfe (1993) analyzed the location determinants of exportoriented foreign direct investment in the Caribbean Basin. The study employed 187 new plant investments based on U.S. Department of Commerce data as the dependent variable and various country-specific aggregate variables, such as per capita GNP, political stability, availability of free trade zones, manufacturing concentration, and land area, as explanatory variables. Thus, these types of studies are not fully micro-oriented and may fail to capture the investment decisions that are based on regional considerations. Firm-specific studies that are carried out on a case-by-case basis are in a better position to incorporate the micro-decision process, but are difficult to generalize in terms of the overall implications for a developing economy.

\section{Survey Data Analysis}

Studies based on survey data that analyze the key motivations of global investors are ideally suited for studying qualitative factors that may be difficult to incorporate into an econometric model. A good example of this approach is Rolfe, et al (1993).

In this study a four-page questionnaire was sent out to U.S.-based managers of companies with international investments. The managers were asked to rank twenty specific incentive schemes. The results indicated that corporate managers placed a high value on not restricting intercompany payments and dividend remittances. The general disadvantage of these studies is the inherent limitations of survey data analysis, particularly the sensitivity of the subjective responses to the structure and style of the survey instrument (for a good discussion of these issues, see Wallsten, 1980). 


\section{Aggregate Econometric Studies}

Aggregate statistical studies attempt to evaluate country-specific determinants of the overall trends in FDI flows. By analyzing data at the macroeconomic level, these studies can provide insights about the type of structural characteristics and macroeconomic policies that may encourage FDI flows. But, because it is difficult to incorporate firm-or industry-level determinants in these macro-oriented studies, the aggregate relationships capture only broad, long-term trends. 


\section{REFERENCES}

Agarwal, J.P. 1980. "Determinants of Foreign Direct Investments: A Survey" Weltwirtschaftliches 116:739-77.

Aharoni, Y.1966. "The Foreign Investment Decision Process" Cambridge, Mass.: Harvard University Press.

Bandera, V.N., and J.T. White, 1968. "US Direct Investments and Domestic Markets in Europe." Economia Internazionale 21: 117-33.

Barro, R. 1991. "Economic Growth in a Cross Section of Countries." Quarterly Journal of Economics, 106 (2): 407-44.

Bennett, P.D. and R.T. Green. 1972. "Political Instability as a Determinant of Direct Foreign Investment in Marketing." Journal of Marketing Research, 9: 162-86.

Brown, R.L., J. Durbin, and J.M Evans. 1975. "Techniques for Testing the Constancy of Regression Relationships Over Time." Journal of Royal Statistical Society, 37: 49-73.

Buckley, P.J. and M. Casson, 1976. "A Long-Run Theory of the Multinational Enterprise." In P.J. Buckley, and M.C. Casson, eds., The Future of Multinational Enterprise. London: Macmillan :32-65

Casson, M. 1990. "The Theory of Foreign Direct Investment." In P. Buckley, ed., International Investment. Aldershot, England: Edward Elgar Publishing Ltd.: 244-73

Caves, M.C. 1982. Multinational Enterprise and Economic Analysis. Cambridge: Cambridge University Press.

Caves, M.C., M.E. Porter, and A.M. Spence. 1980. Competition in the Open Economy, Cambridge, Mass.: Harvard University Press.

Chen, Edward. 1994. "Foreign Direct Investment and Trade as a Vehicle for Rapid Economic Growth: The NIE Experience." Working Paper presented in Colombo, Sri Lanka, Feb. 1994.

Culem, C.G. 1988. "The Locational Determinants of Direct Investment among Industrialized Countries." European Economic Review 32: 885-904.

Dipak, G. 1990. The Economics of Political Violence: The Effect of Political Instability on Economic Growth. New York: Prager. 
Dollar, D. 1992. "Outward-Oriented Developing Economies Really Do Grow More Rapidly: Evidence from 95 LDC's 1976-1985." Economic Development and Cultural Change 40(3): 52344.

Dunning, J.H. 1973. "The Determinants of International Production." Oxford Economic Papers 25: 289-336. and Urwin.

1981. International Production and the Multinational Enterprise. London: Allen

Gooptu, S. 1993. "Portfolio Investment Flows to Emerging Markets." Policy Research Working Papers. World Bank, International Economics Division. Washington D.C.

Flamm, K. 1984. "The Volatility of Offshore Investment." Journal of Development Economics. 16: $231-48$.

Fry, M.J. 1993. "Foreign Direct Investment in a Macroeconomic Framework: Finance, Efficiency, Incentives and Distortions." Working Paper Series 1141. World Bank, International Economics Department, Washington D.C.

Green, R. 1972. "Political Instability as a Determinant of U.S. Foreign Investment." Bureau of Business Research, University of Texas at Austin.

Gupta, V.K. 1983. "A Simultaneous Determination of Structure, Conduct and Performance in Canadian Manufacturing." Oxford Economic Papers 35: 281-301.

Helleiner, G.K. 1989. "Transnational Corporations and Direct Foreign Investment." Handbook of Development Economics, Vol. II. Elsevier Publishers, 1441-80.

Hein, S. 1992. "Trade Strategy and the Dependency Hypothesis: A Comparison of Policy, Foreign Investment, and Economic Growth in Latin America and East Asia." Economic Development and Cultural Change 40(3): 495-521.

Hymer, S. 1960. The International Operations of National Firms: A Study of Direct Foreign Investment. Cambridge, Mass. MIT Press.: (published in 1976).

1971. "The Efficiency (Contradictions) of Multinational Corporations." American Economic Review. 110 (2):

International Finance Corporation. 1992. "Trends in Private Investment in Developing Countries." May.

Kobrin, S. 1981. "Political Risk: A Review and Reconsideration." Journal of International Business (Spring): 67-80. 
Leamer, E. 1985. "Sensitivity Analysis Would Help." American Economic Review 73 (3): 30813.

Letto-Gilles, G. 1992. "International Production, Trends, Theories and Effects." Cambridge: Polity Press.

Levis, M. 1979. "Does Political Instability in Developing Countries Affect Foreign Investment Flow? An Empirical examination." Management International Review 19: 59-68.

Lim, L.Y., and P.E. Fong. 1991. Foreign Direct Investment and Industrialization in Malaysia, Singapore, Taiwan and Thailand." Paris: Development Center of the Organization for Economic Cooperation and Development.

Lucas, R. 1993. "On the Determinants of Direct Foreign Investment: Evidence from East and Southeast Asia." World Development .21 (3): 391-406.

Lunn, J.L. 1980. "Determinants of US Direct Investment in the EEC." European Economic Review 13: 93-101.

Nigh, D. 1985. "The Effect of Political Events on US Direct Foreign Investment: A Pooled Time-Series Cross-Sectional Analysis." Journal of International Business Studies 16: 1-17.

Owen, R.F. 1982. "Inter-industry Determinants of Foreign Direct Investments: a Canadian Perspective." In A.M. Rugman, ed., New Theories of Multinational Enterprise. London: Croom Helm.

Pindyck, R. and D. Rubinfeld. 1991. Econometric Models and Economic Forecasts. McGraw Hill: New York.

Pearce, R., A. Islam, and K. Sauvant. 1992. "The Determinants of Foreign Direct Investment, A Survey of Empirical Evidence." United Nations Centre on Transnational Corporations, United Nations, New York.

Petrochilas, G.A. 1989. Foreign Direct Investment and the Development Process. Aldershot: Avebury.

Rolfe, R., D. Ricks, M. Pointer,. and M. McCarthy. 1993. "Determinants of FDI Incentive Preference of MNEs "Journal of International Business Studies. " 24 (2):335-55.

Root, F. and A. Ahmed. 1979. "Empirical Determinants of Manufacturing Direct Foreign Investment in Developing Countries." Economic Development and Cultural Change 27: 751-67.

Saunders, R.S. 1982. "The Determinants of Inter-Industry Variation of Foreign Ownership in Canadian Manufacturing." Canadian Journal of Economics 15: 77-84. 
Schmitz, A., and J. Bieri. 1972. "EEC Tariffs and US Direct Investments." European Economic Review 3: 259-70.

Schneider, F., and B. Frey, 1985. "Economic and Political Determinants of Foreign Direct Investment." World Development. 13 (2):161-75.

Torrisi, C.R. 1985. "The Determinants of Direct Foreign Investment in a Small LDC." Journal of Economic Development 10 (2): 29-45.

Vernon, R. 1966. "International Investment and International Trade in the Product Cycle." Quarterly Journal of Economics. 80: 190-207.

. 1979. "The Product Cycle Hypothesis in a New International Environment." Oxford Bulletin of Economics and Statistics 41: 255-67.

Wallsten, T. Ed. 1980. Cognitive Processes in Choice and Decision Behavior. Hillsdale, New Jersey: Lawrence Erlbaum.

Westphal, L.E. and others 1979. "Foreign Influences on Korean Industrial Development." Bulletin of the Oxford Institute of Economics and Statistics.

Wheeler, D., and A.. Mody. 1992. "International Investment Location Decisions, the Case of U.S. Firms." Journal of International Economics 33: 57-76.

White, H. 1980. "A Heteroscedasticity-Consistent Covariance Matrix and a Direct Test for Heteroscedasticity." Econometrica, 48: 817-38.

Woodward, D., and R Rolfe,. 1993. "The Location of Export-oriented Foreign Direct Investment in the Caribbean Basin." Journal of International Business Studies 24 (1): 121-44.

World Bank. 1995. World Debt Tables. Washington, D.C. : World Bank. 




\section{Policy Research Working Paper Series}

Title

WPS1517 Inflation Crises and Long-Run Growth

WPS 1518 Sustainability of Private Capital Flows to Developing Countries: Is a Generalized Reversal Likely?

WPS1519 Payment Systems in Latin America: A Tale of Two Countries - Colombia and El Salvador

WPS1520 Regulating Telecommunications in Developing Countries: Outcomes, Incentives, and Commitment

WPS1521 Political Regimes, Trade, and Labor Policies

WPSi522 Divergence, Big Time

WPS1523 Does More for the Poor Mean Less for the Poor? The Politics of Tagging

WPS1524 Employment and Wage Effects of Trade Liberalization: The Case of Mexican Manutacturing

WP\$1525 Is Ethiopia's Debt Sustainable?

WP\$1526 Do We Face a Global "Capital Shortage"?

WPS1527 Foreign Direct Investment, Other Capital Flows, and Current Account Deficits: What Causes What?

WPS1528 Developing Commercial Law in Transition Economies: Examples from Hungary and Russia

WFS1529 Interest Rates, Credit, and Economic Adjustment in Nicaragua

WPS1530 Poverty, Inequality, and Social Policy in Transition Economies
Author

Date

Michael Bruno

William Easterly

Leonardo Hernández

Heinz Rudolph

Robert Listfield

Fernando Montes-Negret

Anmed Galal

Bharat Nauriyal

Arup Banerji

Hafez Ghanem

Lant Pritchett

Jonah B. Gelbach

Lant H. Pritchett

Ana Revenga

Ejaz Ghani

Hyoungsoo Zang

Zia Qureshi

Maxwell J. Fry

Stijn Claessens

Peter Burridge

Marie-Christine Blanchet

Cheryl W. Gray

Kathryn Hendley

Uirich Lächler

Branko Milanovic

\section{Contact for paper}

September 1995

P. Martin

39120

October 1995 R. Vo

31047

October 1995

S. Coca

37664

October 1995

P. Sintim-Aboagye 38526

October 1995

H. Ghanem 85557

October 1995

S. Fallon 38009

October 1995

S. Falion 38009

Octaber 1995

A. Revenga 85556

October 1995

A. Nokhostin 34150

October 1995

V. Barreto

87216

October 1995

ค. Vo

33722

November 1995

G. Evans 85783

November 1995

G. Carter 30603

November 1995

G. Evans 85783 


\section{Policy Research Working Paper Series}

\section{Title}

WPS153
WPS1532 Regulation and Bank Stability: Canada and the United States, 1870-1980

WPS1533 Universal Banking and the Financing of Industrial Development

WPS1534 The Evolution of General Banking

WPS1535 Financial History: Lessons of the Past for Reformers of the Present

WPS1536 Free Banking: The Scottish

Experience as a Model for Emerging Economies
WPS1537 Before Main Banks: A Selective Historical Overview of Japan's Prewar Financial System

WPS1538 Contıngent Liability in Banking: Useful Anthony Saunders Policy for Developing Countries?

WPS1539 The Rise of Securities Markets: What Can Government Do?

WPS1540 Thrift Deposit Institutions in Europe and the United States

WPS1541 Deposit Insurance

WPS1542 The Development of Industrial Pensions in the United States in the Twentieth Century

WPS1543 The Combined Incidence of Taxes and Public Expenditure in the Philippines

WPS1544 Economic Performance in Small Open Economies: The Caribbean Experience, 1980-92

WPS1545 International Commodity Control: Retrospect and Prospect Berry Wilson

Richard Sylla

\section{Author}

Harinder Singh

Kwang W. Jun

Michael Bordo

Charles W. Calomiris

Forest Capie

Gerard Caprio, Jr. Dimitri Vittas

Randall Kroszner

Frank Packer

Dimitri Vittas

Eugene White

Samuel H. Williamson

Shantayanan Devarajan Shaikh 1. Hossain

F. Desmond McCarthy Giovanni Zanalda

Christopher L. Gilbert

\section{November 1995 \\ November 1995 \\ November 1995 \\ November 1995 \\ Date \\ November 1995 \\ November 1995 \\ November 1995 \\ November 1995 \\ November 1995 \\ November 1995 \\ November 1995 \\ November 1995 \\ November 1995 \\ for paper 31047 \\ D. Evans 38526 \\ D. Evans 38526 \\ D. Evans 38526 \\ D. Evans 38526 \\ D. Evans 38526 \\ D. Evans 38526 \\ D. Evans 38526 \\ D. Evans 38526 \\ P. Infante 37642 \\ D. Evans 38526 \\ D. Evans 38526 \\ C. Bernardo 37699 \\ M. Divino 33739}

Contact

S. King-Watson

November 1995
G. llogon 33732 